\title{
Police-involved deaths and the impact on homicide rates in the post-Ferguson era: a study of 44 US cities
}

\author{
Tyler J Lane
}

School of Public Health and Preventive Medicine

Monash University

553 St Kilda Road

Melbourne, VIC Australia

tyler.lane@monash.edu

+61 (0) 459588897

\section{Acknowledgements}

I thank Prof David Humphreys of the University of Oxford, who commented on earlier versions of this manuscript, though the work and any errors within it are entirely my own.

\section{Funding}

This project received no funding. It was completed in the author's spare time. 


\section{Abstract}

This study investigated whether homicides increased after protested police-involved deaths, focusing on the period after Michael Brown's death in Ferguson in August 2014. It also tests for effects of legal cynicism by comparing effects in homicide and aggravated assault on the assumption that reporting of the latter is discretionary and police abuses may make communities reluctant to notify police. Using FBI data from 44 US cities, homicide and assault rates from 2011 to 2019 were analysed using an interrupted time series design and combined in a meta-analysis to calculate pooled effects. A meta-regression tested effect moderators including external investigations and city/county sociodemographic characteristics. With a conservative threshold of $p \leq 0.01,21$ of the 44 cities experienced a significant increase and one had a significant decrease. The pooled effect was a $26.1 \%$ increase in the homicide (99\% CI: $15.3 \%$ to $36.8 \%$ ). Aggravated assaults increased above baseline, though the effect was 15.1 percentage points smaller (99\% CI: -26.7 to -3.6 ) than the effect in homicides. When outcomes were measured as percent change, there were no significant effect moderators, but when measured as absolute change, homicides increased to a greater extent when the death was subject to external investigation and in cities with higher black populations, poverty rates, and baseline homicide rates. The findings suggest that protested police-involved deaths led to an increase in homicides and other violence due to the distrust fomented within the very communities whom police are meant to protect.

\section{Key words}

Homicide; police violence; crime reporting; interrupted time series; legal cynicism; Ferguson effect 


\section{Introduction}

\section{Background}

On 9 August 2014, Officer Darren Wilson shot and killed Michael Brown in Ferguson, a suburb of St Louis, Missouri. Within days, protests erupted across the United States. Riots consumed St Louis, which flared again in November after a grand jury opted not to indict Officer Wilson. Along with the deaths of other black civilians at the hands of police or in their custody, the events of Ferguson galvanised the nascent Black Lives Matter movement, which called for major reforms to address police abuses (Rosenfeld \& Wallman, 2019). The issue of police violence has once again garnered national attention with the killing of George Floyd by Officer Derek Chauvin in Minneapolis on 25 May 2020, (Rosenfeld \& Lopez, 2020).

In the decades leading up to Ferguson, homicides declined across the United States (Rosenfeld \& Fox, 2019). After Ferguson, they increased nationally, by $11 \%$ in 2014/15 and another $8 \%$ in 2015/16 (James, 2018). This was linked to the civil unrest following Brown's death in what has been referred to as the Ferguson Effect. While initially dismissed (Coates, 2015; McMillan Cottom, 2015; Mock, 2015; Rosenfeld, 2015), supporting evidence has since accumulated (Capellan et al., 2020; Gross \& Mann, 2017; Pyrooz et al., 2016; Rosenfeld \& Fox, 2019).

After Ferguson, police-involved deaths in other cities were linked to increases in homicide including the acquittal of the New York City police officer involved in Eric Garner's death (Gross \& Mann, 2017), the death of Freddie Gray following injuries sustained in a Baltimore police van (Gross \& Mann, 2017; S. L. Morgan, 2016; S. L. Morgan \& Pally, 2015), and the release of the footage of Laquan McDonald's death in Chicago (Kapustin et al., 2017). Rather 
than leading directly to a national increase in homicides, Ferguson may have set the stage for local flashpoints to increase homicides in other cities (S. L. Morgan \& Pally, 2015).

\section{Proposed mechanisms - the many faces of the Ferguson Effect}

The precise chain of events from a police-involved death to increased homicide remains opaque (Gross \& Mann, 2017), though there are a number of proposed mechanisms. The term "Ferguson Effect" initially referred to the strain on the St Louis Police Department of monitoring protests and riots in the wake of Michael Brown's death while maintaining regular policing duties (Byers, 2014; Rosenfeld, 2016). It evolved to refer to de-policing, or the intentional pullback from duties in the face of public scrutiny and hostility (Rosenfeld, 2016), sometimes referred to as a "war on cops" (Mac Donald, 2017), or constraints on police activity due to external oversight (Cassell \& Fowles, 2018; Rushin \& Edwards, 2016). However, the de-policing mechanism is generally unsupported by evidence (Capellan et al., 2020; Rosenfeld \& Wallman, 2019; Shjarback et al., 2017). While de-policing has occurred after police-involved deaths, it has not been linked to changes in homicide rates. For instance, after Ferguson arrest rates fell in Baltimore, 800 miles away, yet homicides did not increase until Freddie Gray died in local police custody eight months later (S. L. Morgan \& Pally, 2015). Similarly, among Missouri police departments serving larger black populations, there was a fall in arrests, traffic stops, and searches after Ferguson, though this was unrelated to crime (Shjarback et al., 2017). Cassell \& Fowles (2018) attributed the rise of homicide in Chicago starting in December 2015 to an ACLU investigation and a resulting consent agreement that drastically reduced stop and frisks. However, this coincided with the release of footage showing Chicago police shooting and killing Laquan McDonald, which could also explain the effect. De-policing and homicide increases may therefore be independent outcomes of police-involved deaths rather than sequential and causal steps. 
An alternative mechanism is legal cynicism, or "a cultural orientation in which the law and agents of its enforcement, such as the police and courts, are viewed as illegitimate, unresponsive, and ill equipped to ensure public safety" (Kirk \& Papachristos, 2011, p. 1191). Legally cynical communities may be reluctant to turn to the formal justice system of police and judges, preferring to instead resolve disputes within the community (Gross \& Mann, 2017; Kirk \& Papachristos, 2011; Leovy, 2015; O’Flaherty \& Sethi, 2019; Rosenfeld et al., 2017). Correspondingly, neighbourhoods high in legal cynicism also have higher homicide rates (Kirk \& Papachristos, 2011). Legal cynicism is higher in black and deprived neighbourhoods and in the wake of Ferguson, these demographic factors predicted larger increases in homicide (Gross \& Mann, 2017; Lauritsen \& Lentz, 2019; Pyrooz et al., 2016). However, the association between black neighbourhoods and legal cynicism attenuates to non-significance when adjusting for socio-economic deprivation and pre-existing levels of violent crime (Sampson \& Bartusch, 1998).

Police abuses that garner wider community attention may increase legal cynicism, leading to disengagement the formal justice system. When news broke that off-duty Milwaukee police officers battered Frank Jude, an unarmed black man, calls to 911 emergency services gradually declined, particularly in black neighbourhoods, and only returned to baseline after a year (Desmond et al., 2016). Cassell \& Fowles (2018) argue that police-involved deaths are unlikely to be the causative factor because they reveal nothing new about police departments with a long history of racial abuse. However, those histories of racial abuse likely turn policeinvolved deaths into a catalyst for a breakdown in policy-community relations (Gross \& Mann, 2017). A pair of Justice Department reports on the death of Michael Brown in Ferguson largely exonerated Officer Wilson and concluded community anger was directed towards systemic racial abuse by police and municipal and city officials who enforced petty municipal violations against black community members as a revenue-generating strategy 
(United States Department of Justice, 2015; United States Department of Justice Civil Rights Division, 2015).

Instead of being a focus, Brown's death may have been the flashpoint for community discontent to boil over. Desmond et al (2016) argue "high-profile cases of excessive police force constitute a severe breach in the social contract that exists between citizens and the criminal justice system" (p. 871). As a consequence, communities may turn to the considerably more violent informal justice system to resolve conflicts (Leovy, 2015). In such circumstances, murder may even become a pre-emptive strategy of self-preservation, i.e., kill or be killed (Gross \& Mann, 2017; O'Flaherty \& Sethi, 2019).

\section{Evidence gaps and research questions}

The present evidence base either relies on annual aggregations (which result in less precise estimates than smaller-level aggregations), only tests Ferguson rather than local events (Gaston et al., 2019; Gross \& Mann, 2017; James, 2018; Pyrooz et al., 2016; Rosenfeld, 2015, 2016; Rosenfeld et al., 2017; Rosenfeld \& Wallman, 2019), or is limited to a single city or event, risking history bias (Capellan \& Lautenschlager, 2019; Cassell \& Fowles, 2018; Kapustin et al., 2017; S. L. Morgan, 2016; S. L. Morgan \& Pally, 2015). One exception is Vandegrift \& Connor (2020), who found that after Ferguson, homicides fell by $3.8 \%$ on average after police-involved deaths. However, they made no distinction between policeinvolved deaths that were protested and those which were not, which may not adequately capture events that increase legal cynicism.

To test whether legal cynicism increased following police-involved deaths, this study compares effects between homicide and aggravated assault rates. Previous work has found that while other crimes increased post-Ferguson, the magnitudes were smaller than observed in homicide (Devi \& Fryer Jr., 2020; Gross \& Mann, 2017; Lauritsen \& Lentz, 2019). 
Assaults may be similar to homicide as a conflict-resolution strategy, particularly if policeinvolved deaths turn communities away from the formal justice system. However, unlike homicide, reporting of assault is discretionary. If protested police-involved deaths increase legal cynicism, community members may report fewer assaults to the police, while nearly all homicides will still be reported. Even if actual homicides and assaults increase at the same rate, a drop in reporting would result in a divergence in offences recorded by police, with a larger observed effect in homicides.

This study is guided by the following research questions: In the post-Ferguson era, 1) Did homicides increase in cities where there was a protested police-involved death? 2) As a test of legal cynicism, was there a smaller effect in assaults, which would suggest a reduction in reporting and community engagement with police?

\section{Methods}

\section{Data}

Homicide and aggravated assault data from 2011 to 2019 were derived from the FBI's Uniform Crime Reporting (UCR) Program Data (Kaplan, 2020). Louisville and Raleigh were not in the UCR and were instead downloaded from their city data portals (Louisville Open Data, 2020; Raleigh Open Data, 2020). Tampa was also not available in the UCR and was acquired via a request to the police department. Annual population estimate denominators were from UCR and the United States Census Bureau (United States Census Bureau, 2020).

\section{City-events selection}

Events were specified as police-involved deaths in the post-Ferguson Era (August 2014) up to 2016 that resulted in a protest. Cities were limited to those with populations of at least 200,000 as of 2010 (United States Census Bureau, 2020), which provided a range of at least 
three years of pre- and post-event data. Police-involved deaths were identified via the Washington Post's Fatal Force database (Tate et al., 2020) and common knowledge of other well-known events that did not appear in the dataset because they occurred prior to 2015 (e.g., Laquan McDonald in Chicago, Tamir Rice in Cleveland, both in 2014) or were not shootings (e.g., Eric Garner in New York, Sandra Bland outside of Houston, Freddie Gray in Baltimore). Victim name, city, and the word "protest" were searched in Google for relevant news articles. Those with at least one article indicating a local protest were classified as eligible. A list of all searched police-involved deaths with a link to news articles for those that were protested is archived along with other study materials on a public repository (Lane, 2019).

Where police-involved deaths occurred in suburbs rather than the city, as with Ferguson (Michael Brown, St Louis) and Falcon Heights (Philando Castile, Minneapolis-St Paul), city and suburb data were merged. Where homicide counts were low and there was geographic contiguity, urban centres were combined, such as Charleston-North Charleston, Dallas-Fort Worth-Arlington, and Minneapolis-St Paul.

Several deaths were protested at several discrete points as communities responded to new developments such as a decision not to indict involved officers or the release of footage. For instance, Eric Garner's death on 17 July 2014 in New York was immediately followed by small protests, though larger-scale protests came after the involved officer was acquitted on 3 December 2014 (Gross \& Mann, 2017).

\section{Outcomes}

Primary outcomes were the rate of homicide and aggravated assault. Both were aggregated quarterly, providing greater precision than annual aggregations (Shadish et al., 2002) while also allowing the study to include several cities with low homicide counts. 
Homicides include unjustified murder and non-negligent manslaughter as per Department of Justice and FBI definitions (United States Department of Justice \& Federal Bureau of Investigation, 2013). Aggravated assault is defined as "an unlawful attack by one person upon another for the purpose of inflicting severe or aggravated bodily injury...[that] usually is accompanied by the use of a weapon or by means likely to produce death or great bodily harm" (United States Department of Justice \& Federal Bureau of Investigation, 2013, p. 37). This outcome was selected for its similarity to homicide as interpersonal violence that may be used for a conflict-resolution in communities high in legal cynicism, though with discretionary reporting. While nearly all homicides are reported to police (Kirk \& Papachristos, 2011; Rosenfeld, 2018), in 2013, the year before Michael Brown's death, National Crime Victimization Survey data ${ }^{1}$ estimate only $64 \%$ of aggravated assaults were reported to police (Bureau of Justice Statistics, 2019). If protested police-involved deaths increase legal cynicism, actual homicides and aggravated assaults may increase at the same relative rate, though the latter may appear lower in official statistics due to a fall in those reported to police.

\section{Effect moderators}

Several factors were tested to determine whether they influence effects. Federal and state investigations of police departments following a police-involved death may introduce external regulation that result in de-policing (Cassell \& Fowles, 2018; Devi \& Fryer Jr., 2020; Rushin \& Edwards, 2016). Investigations were identified using PBS's Fixing the Force database (Childress et al., 2020) and Devi \& Fryer (2020). Whether the involved officer was not indicted or acquitted was another moderator. Other moderators were based on factors that

\footnotetext{
${ }^{1}$ The National Crime Victimization Survey regularly captures the proportion of aggravated assaults that are reported to police, which theoretically could serve as a useful check as to whether reporting actually decreased. Unfortunately, the data were too variable to derive meaningful inferences. See the Appendix for more details. 
have been previously associated with post-Ferguson homicide rate increases (Gross \& Mann, 2017; James, 2018; Pyrooz et al., 2016; Vandegrift \& Connor, 2020) including whether the victim was black, county poverty rates (United States Census Bureau, 2014), percent black population (United States Census Bureau, 2010), and homicide rate in the 12 months prior to Ferguson.

\section{Analysis}

Each police-involved homicide was tested using an interrupted time series study design with generalised least squares regression models. Homicide and aggravated assault rates were included in the same model, with effects in assaults estimated relative to effects in homicide. The dispersion of police-involved deaths produce multiple baselines, which minimises the risk of history bias (Biglan et al., 2000; Hawkins et al., 2007). To account for the 25 -fold difference between frequencies of homicide and aggravated assault (R. E. Morgan \& Truman, 2018), the latter was indexed to the homicide rate in the 12 months pre-Ferguson. Homicide and indexed assault rates were log-transformed to estimate percent rather than absolute changes (Beard et al., 2019).

To centre the intercept at the event, the running time variable was calculated so the event quarter was 1; e.g., if the time series started 10 quarters before the event and ended ten quarters afterwards, counting would start at -9 and end at +10 . Data points corresponding to the event (e.g., 2014 Q3 for the death of Michael Brown) were excluded from analysis as a "phase-in" period to avoid mixing pre- and post-event periods in the same data point.

To account for seasonality, regression models included two pairs of sine and cosine terms that were retained only if significant at $p \leq 0.05$ (Jebb et al., 2015). Residual autocorrelation was identified using autocorrelation and partial autocorrelation function plots up to lag 4 and corrected with ARMA (autoregressive-moving average) terms (Fox \& Weisberg, 2018), and 
the best-fitting model selected using the Akaike Information Criterion (Jebb et al., 2015). Where there were multiple deaths or protests in a single city, only one model was selected for reporting, also based on the Akaike Information Criterion. Effects are reported as acute changes to the intercept and gradual changes to the slope (Shadish et al., 2002).

A random-effects meta-analysis was used to pool effects and calculate the proportion of variance attributable to heterogeneity. Effect moderators were individually tested in metaregressions. Continuous moderator variables were transformed to z-scores to make coefficients comparable. There was a risk of selection bias due to reliance on media reports to identify protested police-involved death; e.g., protests may have been more likely to make the news if they were followed by violence. Three tests of selection bias, a funnel plot, Egger's regression, and trim-and-fill points, were conducted on acute homicide effects.

Statistical significance was set at a conservative $p \leq 0.01$ to account for multiple comparisons and limit the risk of Type 1 errors. Analyses were conducted in R (R Core Team, 2020) with RStudio (RStudio Team, 2020), using the following packages: broom.mixed (Bolker \& Robinson, 2020), forecast (Hyndman et al., 2019), ggpubr (Kassambara, 2019), janitor (Firke, 2020), lubridate (Grolemund \& Wickham, 2011), magrittr (Bache \& Wickham, 2014), metafor (Viechtbauer, 2010), metaviz (Kossmeier et al., 2019), nlme (Pinheiro et al., 2020), scales (Wickham \& Seidel, 2019), see (Lüdecke et al., 2019), tidyverse (Wickham et al., 2019), and zoo (Zeileis \& Grothendieck, 2005). Table data from PDFs were extracted using Tabula (Aristarán et al., 2012). Data and code are archived on a public Bridges repository (Lane, 2019).

\section{Results}

Eighty-three protested police-involved deaths were identified, with 100 discrete events. Several cities' data were not available in the UCR and the local police department were 
unable to provide data (Jacksonville) or there were quarters with no homicides that could not be addressed with the aggregation of nearby cities and suburbs (Des Moines, Madison, Montgomery). Miami-Dade and Miami Police Departments provided data, though the latter were missing large time periods that were not supplied after follow-up requests. After selecting for best-fit events in cities where there were several protested police-involved deaths, 44 city-models remained. The July 2012 movie theatre shooting in Aurora resulted in an extreme outlier, which was adjusted for with a dummy-coded variable.

Acute and gradual effects are illustrated in the forest plot in Figure 1 and a summary of fitted lines with pooled effects are mapped in Figure 2. Individual interrupted time series plots can be found in Supplementary figure 1 and full model results in Supplementary table 1. 


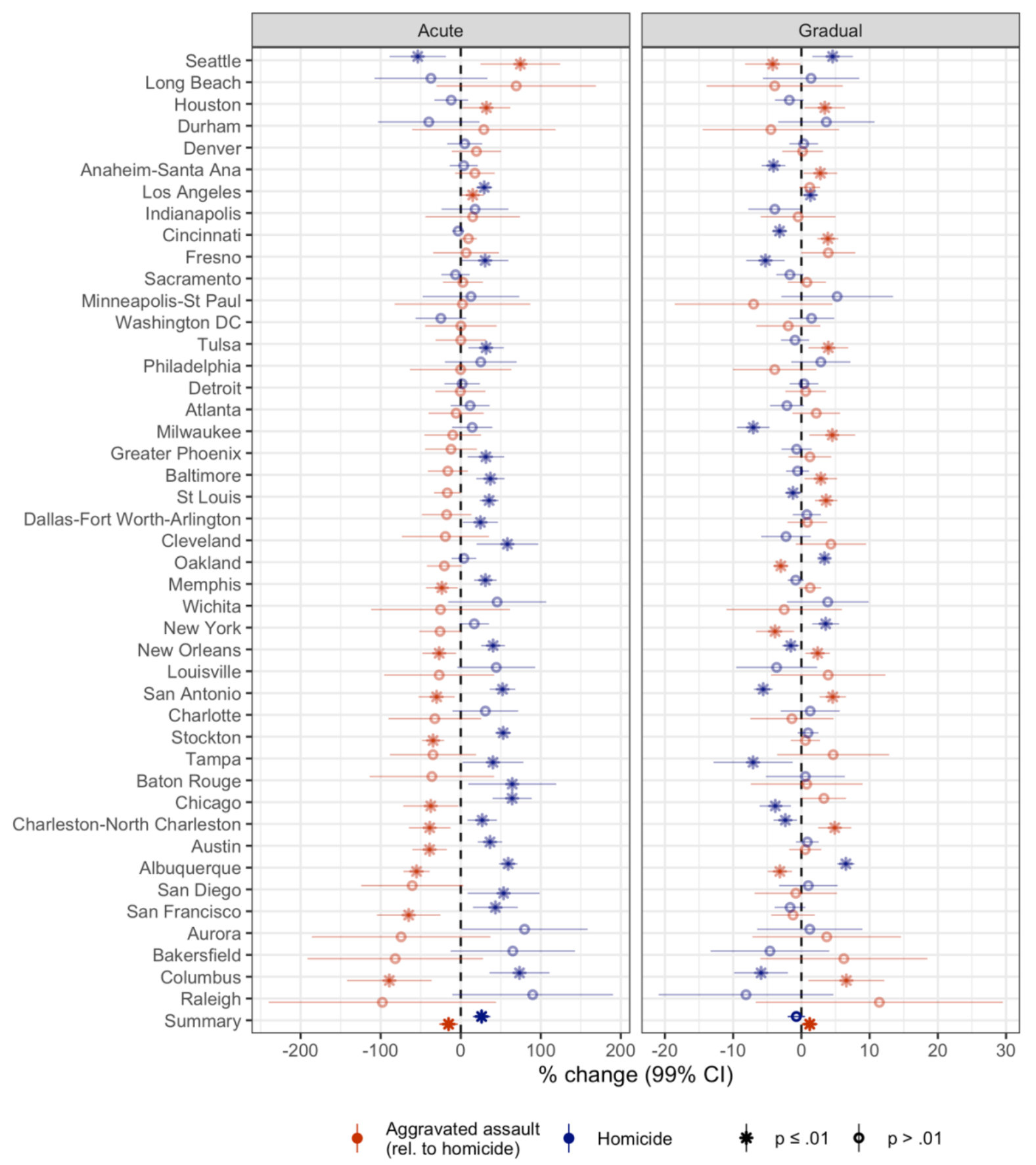

Figure 1. Forest plot, acute and gradual effect sizes on homicide and relative assault rates with 99\% Confidence Intervals 


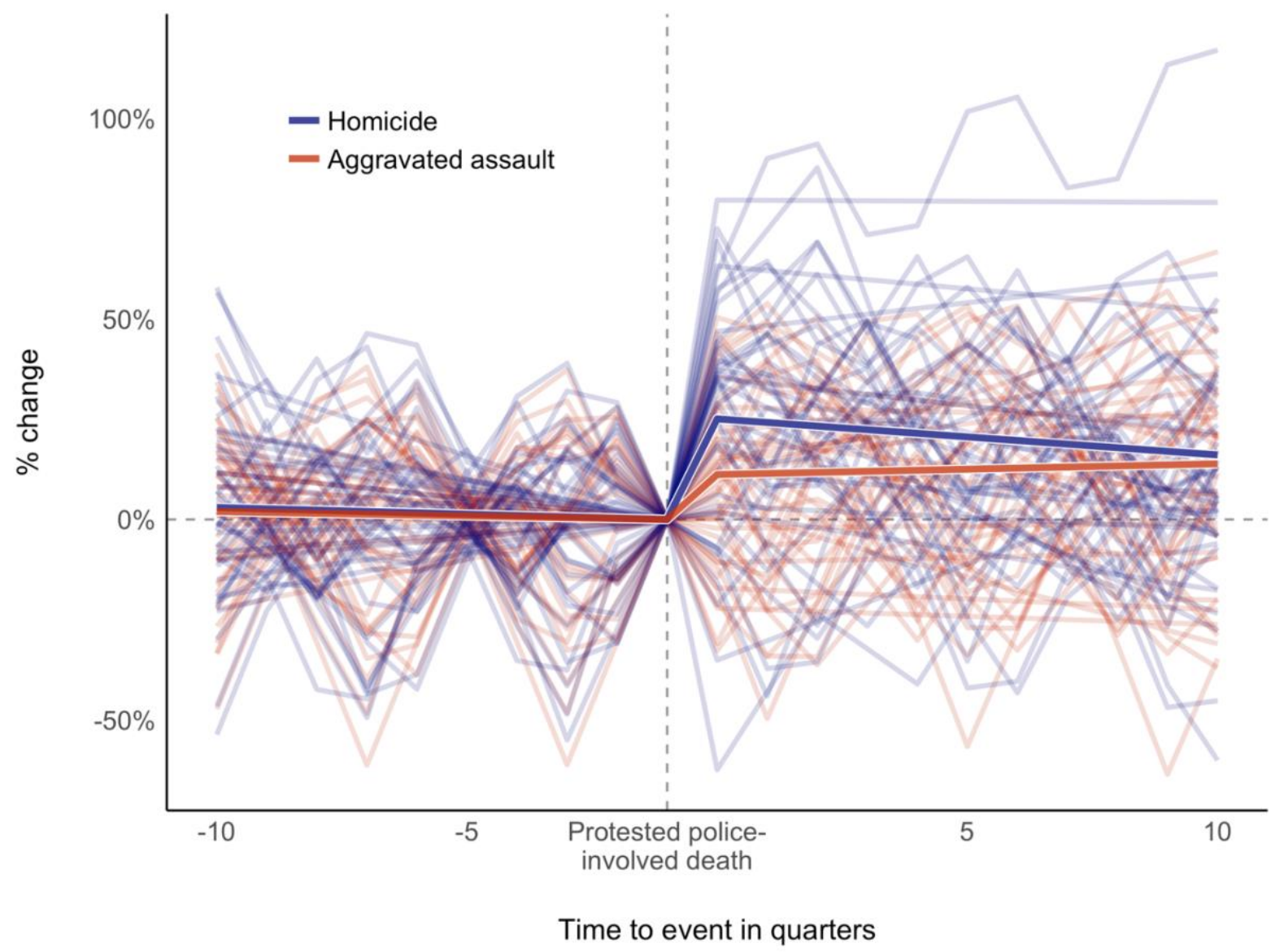

Figure 2. Interrupted time series regression lines with pooled effects superimposed, centred at protested event

\section{Effect of police-involved deaths events on homicide}

Homicides increased $26.1 \%$ (99\% CI: $15.3 \%$ to $36.8 \%$ ) on average following protested police-involved deaths. There was no detectable gradual effect (-0.7\%/quarter; 99\% CI: $2.0 \%$ to $0.5 \%)$. The vast majority of variance in acute effects was attributable to heterogeneity $\left(I^{2}: 91 \%\right)$. Acute effects were significant in half the cities (22 of 44). Only Seattle WA was negative $(-53.7 \%$; $99 \%$ CI: $-88.9 \%$ to $-18.5 \%)$. The largest significant increases were observed in Columbus (73.4\%; 99\% CI: 36.0\% to 110.9\%), Baton Rouge (64.4\%; $99 \%$ CI: $9.4 \%$ to $119.3 \%$ ), and Chicago (64.2\%; $99 \%$ CI: $39.7 \%$ to $88.7 \%$ ). 
Relative to homicide effects, the acute assaults effect was -15.2 percentage points smaller (99\% CI: $-26.7 \%$ to $-3.6 \%$ ); subtracting this from the homicide effect indicates that reported assaults increased $10.9 \%$ above baseline. The majority of variance in acute effects was attributable to heterogeneity $(I: 84 \%)$. Effects were significant in 13 of the 44 cities; 10 were negative, indicating a smaller effect than homicides, and three were positive. There was a significant gradual increase of $1.2 \%$ /quarter $(0.1 \%$ to $2.4 \%)$, indicating a reconvergence with homicide rates over time, which can be seen in Figure 2. Both remain elevated above baseline.

\section{Risk of bias assessment}

There was no detectable selection bias, as illustrated in Figure 3. The asymmetry between acute homicide effects and standard errors was non-significant $(\mathrm{z}=0.78 ; p=0.438)$. The addition of trim-and-fill points to correct reduced the pooled homicide effect to a $22.5 \%$ increase (99\% CI: $14.2 \%$ to $30.9 \%$ ), which remained significant at the $p \leq 0.01$ threshold. 


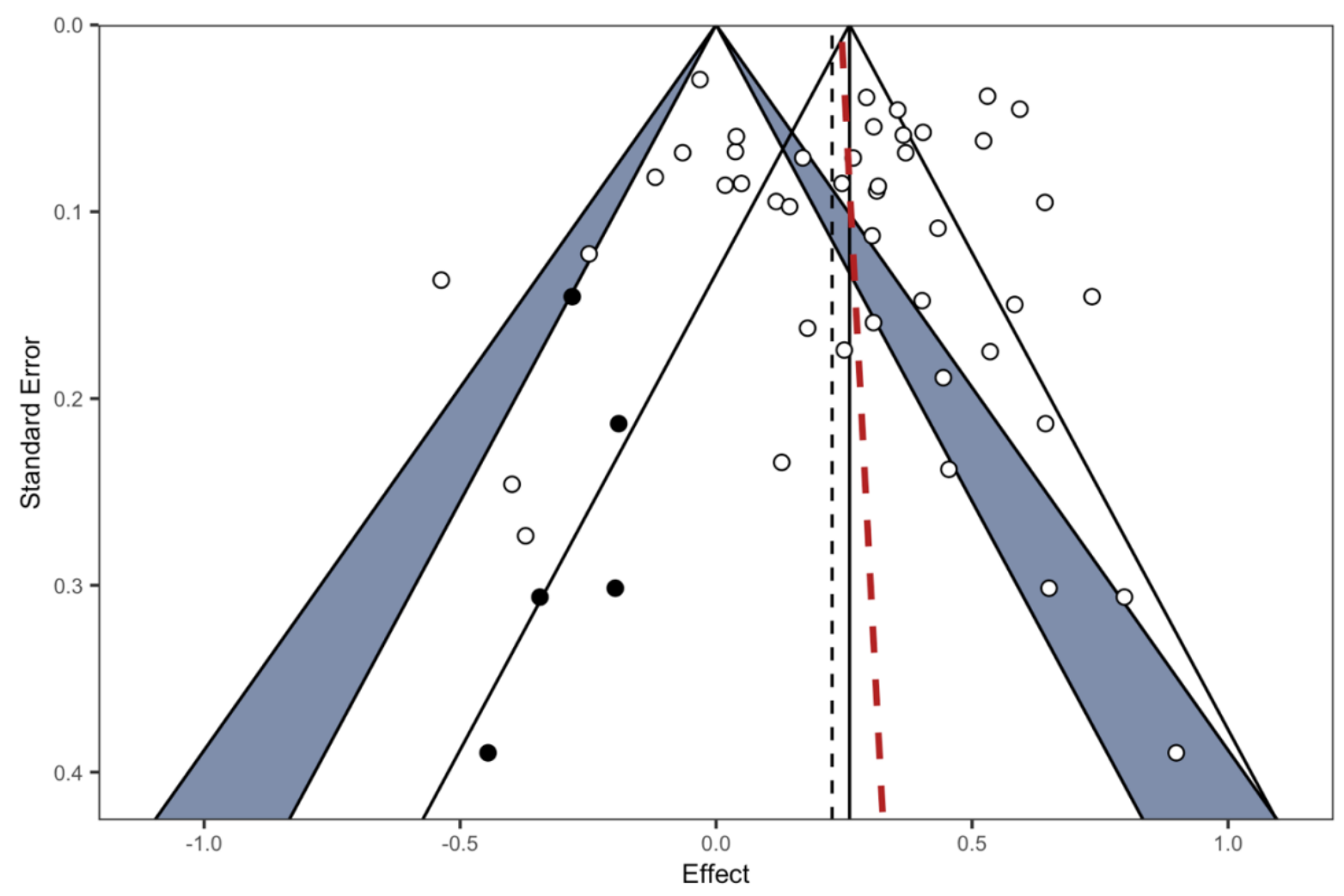

Figure 3. Acute homicide effects funnel plot and trim-and-fill points (in black) to adjust for bias in site selection; the red dashed line represents the Egger's test adjustment

\section{Effect moderators}

No factors significantly moderated acute homicide effects or the gap between homicide and assault rates. As this was inconsistent with previous research, it was explored in some depth.

While this study found no moderation by victim race, Vandegrift \& Connor (2020) found homicides increased when the victim was black and decreased when they were non-black. However, this study included police-involved deaths regardless of whether they were protested. Williamson, Trump, \& Einstein (2018) found protests were more likely when victims of police-involved deaths were black. The same was found using the Washington Post's Fatal Force data: when the victim was black, the odds of protest increased nearly five- 
fold (Odds Ratio: 4.85; 99\% CI: 2.59 to 9.57$).{ }^{2}$ Therefore, while police-involved deaths with black victims are more likely to protested, limiting analyses to protested events had the effect of conditioning on the collider, which blocked the causal pathway between victim race and homicide effects (victim race -> protests $->$ homicide effect).

The next check was whether log-transforming the outcome (to estimate percent change) masked drivers of absolute difference, particularly where baseline homicide rates varied drastically. For instance, if homicides in one city increased from 2 to 3 per 100,000 and another city increased from 20 to 30 per 100,000, the proportional increases would be the same $(50 \%)$, but there would be a 10 -fold difference in absolute magnitudes. Analyses were repeated without log-transforming outcomes to generate absolute effects. Four of the six moderators became significantly associated with outcomes at $p \leq 0.01$ : external police department investigation (2.6 more homicides per 100,000 population; $99 \%$ CI: 1.3 to 3.9 ), and a standard deviation increase in the percent black population $(0.7 ; 99 \% \mathrm{CI}: 0.2$ to 1.1$)$, the poverty rate $(0.6 ; 99 \% \mathrm{CI}: 0.2$ to 1.1$)$, and the pre-Ferguson homicide rate $(0.8 ; 99 \% \mathrm{CI}$ : 0.4 to 1.2$)$. For reference, the pooled absolute homicide rate increase was $1.0 / 100,000$ (99\% CI: 0.5 to 1.5$)$. Absolute effects are summarised in Supplementary table 2.

When all significant moderators of absolute homicide effects were included in a multivariable meta-regression, only an external investigation of the police department was associated with a significantly higher homicide rate (1.8; $99 \% \mathrm{CI}: 0.5$ to 3.0). An additional check was conducted on whether sociodemographic factors were predictive of investigations. None were significant at the conservative alpha of .99, which was unsurprising considering the low power entailed by only four investigations among 44 protested events. However, the

\footnotetext{
2 This analysis was limited to the Washington Post's Fatal Force dataset because it had been systematically collected. Including common-knowledge events that are well known because of the surrounding protests would have introduced collider bias between victim race and protest.
} 
direction of effect suggested that investigations were more likely where the pre-Ferguson homicide rate (OR: 2.43; $99 \%$ CI: 0.77 to 8.93 ), percent black population (OR: 2.22 ; $99 \%$ CI: 0.61 to 10.10$)$, and the poverty rate (OR: 3.58 ; $99 \%$ CI: 0.92 to 23.6$)$ were higher. Metaanalysis and meta-regressions results are summarised in Table 1. 
Table 1. Meta-regression moderator effects on homicide and aggravated assault effects

\begin{tabular}{|c|c|c|c|c|c|c|c|c|}
\hline & \multicolumn{4}{|c|}{ Proportional effects (log-transformed outcomes) } & \multicolumn{4}{|c|}{ Absolute effects (sensitivity analysis) } \\
\hline & \multicolumn{2}{|c|}{$\begin{array}{c}\text { Change in homicide rate } \\
\text { (univariate) }\end{array}$} & \multicolumn{2}{|c|}{$\begin{array}{c}\text { Gap between homicide } \\
\text { and assault rate effects } \\
\text { (univariate) }\end{array}$} & \multicolumn{2}{|c|}{$\begin{array}{l}\text { Change in homicide rate } \\
\text { (univariate) }\end{array}$} & \multicolumn{2}{|c|}{$\begin{array}{c}\text { Change in homicide rate, } \\
\text { significant moderators } \\
\text { (multivariable) }\end{array}$} \\
\hline & Effect & $99 \% \mathrm{Cl}$ & Effect & $99 \% \mathrm{Cl}$ & Effect & $99 \% \mathrm{Cl}$ & Effect & $99 \% \mathrm{Cl}$ \\
\hline $\begin{array}{l}\text { Investigation of police } \\
\text { department }\end{array}$ & 23.6 & $(-13.0$ to 60.2$)$ & -14.3 & $(-54.3$ to 25.8$)$ & 2.6 & $(1.3 \text { to } 3.9)^{* *}$ & 1.8 & $(0.5 \text { to } 3.0)^{* *}$ \\
\hline $\begin{array}{l}\text { Officer not } \\
\text { charged/acquitted }\end{array}$ & -16.0 & $(-40.9$ to 8.9$)$ & 14.4 & $(-12.3$ to 41.1$)$ & -0.1 & $(-1.3$ to 1.1$)$ & - & \\
\hline Black victim & -4.4 & $(-31.7$ to 22.9$)$ & -4.8 & $(-34.3$ to 24.7$)$ & 0.4 & $(-0.9$ to 1.6$)$ & - & \\
\hline $\begin{array}{l}\text { Black population \% (z- } \\
\text { transformed) }\end{array}$ & -1.3 & $(-12.0$ to 9.4$)$ & -0.1 & $(-11.5$ to 11.3$)$ & 0.7 & $(0.2 \text { to } 1.1)^{* *}$ & 0.2 & $(-0.4$ to 0.7$)$ \\
\hline $\begin{array}{l}\text { Poverty rate (z- } \\
\text { transformed) }\end{array}$ & 3.6 & (-7.5 to 14.7$)$ & 0.2 & $(-12$ to 12.4$)$ & 0.6 & $(0.2 \text { to } 1.1)^{* *}$ & 0.1 & $(-0.3$ to 0.5$)$ \\
\hline $\begin{array}{l}\text { Pre-Ferguson } \\
\text { homicide rate (z- } \\
\text { transformed) }\end{array}$ & -1.2 & $(-11.8$ to 9.4$)$ & 1.3 & (-9.9 to 12.4$)$ & 0.8 & $(0.4 \text { to } 1.2)^{* *}$ & 0.3 & $(-0.3$ to 1$)$ \\
\hline
\end{tabular}

** $p \leq .001 ; * p \leq .01$ 


\section{Discussion}

On average, homicides increased $25.7 \%$ in cities where there were protested police-involved deaths. Aggravated assaults also increased, though only by $10.9 \%$, a significantly smaller margin. This is consistent with the study hypothesis, which proposed that a change in assaults would fail to keep up with a change in homicides due to a fall in reporting. However, there are some limits to interpreting a smaller effect in assaults as evidence of a legal cynicism, much less a mechanism for increased homicide. First, these effects are concurrent, essentially making the association cross-sectional. Second, they may reflect real differences in homicide and assault effects rather than divergent reporting. In the context of legal cynicism, the rejection of formal justice, and endemic violence, homicide may be the favoured pre-emptive strategy to resolve conflict or avoid becoming a victim (Gross \& Mann, 2017; O'Flaherty \& Sethi, 2019).

An increase in the lethality of assaults, particularly where a firearm is involved, could also result in a divergence between homicide and assault effects. Between 2014 and 2016, homicides committed with a gun increased much more substantially than by other means (Rosenfeld \& Fox, 2019). Firearms have also become more deadly over time, with higher capacities and larger calibre bullets, which has been offered as a potential explanation for the substantial increases observed since Ferguson (Rosenfeld \& Fox, 2019). Yet a gradual increase in firearm deadliness cannot adequately explain the sharp increases in homicide and assaults since Ferguson (Lauritsen \& Lentz, 2019). An explanation that better fits these observations is a behaviour change within a communities, where people arm themselves more frequently when the formal justice system is perceived as unreliable; the wide proliferation of firearms just makes it easier to do so (Lauritsen \& Lentz, 2019). Further, increased lethality by itself does not explain the increase in assault; if anything, this would reduce the number of 
assaults as a larger share end in death and are classed as homicides. However, an increase in community members arming themselves and a fall in assault reporting are not necessarily mutually exclusive. Both could be consequences of legal cynicism that result in proportionally greater increases in homicides than reported assaults.

In contrast to this study's findings of acute increases in homicide and assault, others have found gradual effects. In one of these studies, Desmond et al (2020) argue "it takes time for legal cynicism to swell and spread in such a way that it could influence citizen crime reporting" and that it would not result in a "clean, clear break" (p. 4). The discrepancy may be due to differences between passive and active events used in these studies. Desmond et al (2016, 2020) used media reports of police violence, while Vandegrift \& Connor (2020) used the death itself; both are passive events which say nothing about the community response. In contrast, this study used protests, an active response that demonstrates wider community awareness and anger. Another source of variation is the level of aggregation. Desmond et al aggregated by week and Vandegrift \& Connor by month, while this study used quarters, which could collapse the lag between event and response. The use of active events may also explain the substantial differences in the observed magnitude of homicide effects. Vandegrift \& Connor (2020) found homicides only increased 3.8\%, a fraction of what was found in this study, though they examined police-involved deaths regardless of whether they were protested. Similarly, Gaston et al (2019) found limited evidence for an effect of protests on homicides, though the protests in this case were not tied to local police-involved deaths. This suggests that a police-involved death must rise to the level of a community protest to have the relatively large effect observed in this study.

While nearly all the variance in effects was attributable to heterogeneity, no moderators were significantly associated with effects on log-transformed outcomes. However, most became significant when effects were not log-transformed and measured in terms of absolute 
changes. This suggests that much of the previously-observed influence of sociodemographic factors such as percent black population, poverty rate, and pre-existing violence (Gross \& Mann, 2017; Pyrooz et al., 2016) is attributable to baseline differences between cities. Neither approach is inherently right or wrong, though this highlights the importance of considering how effect magnitudes are presented and what they mean.

In contrast to previous work, this study found little evidence that external investigations of the police department moderated homicide effects. Rushin \& Edwards (2016) found that federal investigations of police abuses were followed by an increase in homicides, though the effect attenuated slightly to non-significance with the addition of sociodemographic controls. Devi \& Fryer (2020) found that homicides increased substantially following five separate police-involved deaths that were subject to external investigation, though the same was not true for eight police-involved deaths that were not investigated. However, the authors used an admittedly ad hoc approach to identify these latter events, referring to a New York Times list of "viral" fatal police shooting videos with at least two million views. Unlike local protests, the number of views a shooting video receives says little about the community response. In contrast, 18 of the 21 cities in this study where homicides significantly increased had not been subject to an external investigation of the police department. Further, Devi \& Fryer found homicides decreased following 22 external investigations that were not preceded by a "viral" police-involved death. This again suggests that community response is a key factor in homicide rate increases.

While sociodemographic factors (higher pre-Ferguson homicide rates, percent black population, and poverty rate) were not significantly predictive of investigations, the direction of associations suggests investigations are dependent on characteristics of the community. Investigations may be the consequence of unrest, which is more characteristic of areas with 
higher baseline violence and histories of tension between police and communities (Devi \& Fryer Jr., 2020; United States Department of Justice Civil Rights Division, 2015).

As this paper, which covers sensitive topic in highly charged times, comes to a close, the author feels the need to clarify that these results do not suggest that protests are the cause of homicide rate increases. Rather, protests are indicators of community anger over police abuses, which lead to legal cynicism and greater reliance on informal and unfortunately more violent systems of justice. These findings should in no way be used to discourage or condemn peaceful protests, which can have positive effects such as reducing police-involved deaths (Campbell, 2021; Skoy, 2020). Preliminary reports suggest that homicides have again increased following the wave of protests after George Floyd's death in Minneapolis (Rosenfeld \& Lopez, 2020). While the conviction of Officer Derek Chauvin for Floyd's death likely averted further unrest and stemmed community anger, it is unclear whether the present increase in homicides will be sustained, particularly within the new social arrangements under the Covid-19 pandemic.

\section{Strengths and limitations}

Study strengths include use of a robust quasi-experimental study design to analyse population-level crime data, and quarterly aggregations to increase precision of estimates. Significance was set at a conservative $p \leq 0.01$ to reduce the risk of a Type 1 Error, and results were combined into meta-analyses to determine whether there was a general effect, limiting the risk of a Type 2 Error. The use of 44 separate city-event models and multiple baselines reduced potential confounding from history bias and provided sufficient data points for meta-regression analyses. Funnel plots and Egger's test suggest minimal if any selection bias. 
There are several limitations. The first is the test of legal cynicism, specified as a gap between homicide and aggravated assault effects, is at best cross-sectional. The second is the lack of a control group. This was partially because the Ferguson Effect and other policeinvolved deaths may have affected homicide rates around the country (Gross \& Mann, 2017; James, 2018; Pyrooz et al., 2016). Potential control cities were likely contaminated to some degree, which would bias results towards null. Further, many of the cities with high and stable homicide rates had their own local police-involved death, meaning there were few if any suitable comparators.

\section{Conclusions}

In the post-Ferguson Era, cities experiencing protests following police-involved deaths saw substantial increases in homicides and, to a lesser extent, aggravated assaults. While the precise mechanism is unclear, the findings are in line with the a priori hypothesis that police abuses increase legal cynicism, which leads communities to rely less on the formal justice system and resolve disputes internally, informally, and unfortunately, more violently.

\section{Appendix: Analysis of National Crime Victimization Survey data}

The National Crime Victimization Survey captures data on whether respondents were victims of an aggravated assault, and whether they reported the assault to police. Customisable aggregated data can be accessed via the NCVS Victimization Analysis Tool (Bureau of Justice Statistics, 2019). These data were used to directly test the mechanism of reducing reporting of aggravated assaults to police as a result of Michael Brown's death in Ferguson and other protested police involved deaths. The full range of responses (as of writing, 1993 to 2019) were analysed using similar methods to those applied in the manuscript: interrupted time series with a log-transformed dependent variable. Since survey data were annual and 
national (i.e., not distinguished between locations), the event was given as 2014, the year of Michael Brown's death. Results are presented in Supplementary table 3 and illustrated in Supplementary figure 2 .

No effects were significant. However, there was a high degree of variability, as is visible in the wide confidence intervals. This is particularly true of black respondents. The issue likely relates to small numbers, i.e., those who were victims of aggravated assault, and those who were black and victims of aggravated assault. Further, given the survey's annual and national nature, it lacked the precision to capture the effect of city-level events that occurred over several years.

\section{References}

Aristarán, M., Tigas, M., Merrill, J. B., Das, J., Frackman, D., \& Swicegood, T. (2012). Tabula (1.2.1).

Bache, S. M., \& Wickham, H. (2014). magrittr: A Forward-Pipe Operator for R (1.5).

Beard, E., Marsden, J., Brown, J., Tombor, I., Stapleton, J., Michie, S., \& West, R. (2019). Understanding and using time series analyses in addiction research. Addiction, 114(10), 1866-1884. https://doi.org/10.1111/add.14643

Biglan, A., Ary, D., \& Wagenaar, A. C. (2000). The value of interrupted time-series experiments for community intervention research. Prevention Science, 1(1), 31-49. https://doi.org/10.1080/01635581.2014.951737.Intake

Bolker, B., \& Robinson, D. (2020). broom.mixed: Tidying Methods for Mixed Models (0.2.6). Bureau of Justice Statistics. (2019). NCVS Victimization Analysis Tool. https://www.bjs.gov/index.cfm?ty=nvat

Byers, C. (2014). Crime up after Ferguson and more police needed, top St. Louis area chiefs say. In St Louis Post-Dispatch. https://www.stltoday.com/news/local/crime-and- 
courts/crime-up-after-ferguson-and-more-police-needed-top-st/article_04d9f99f-9a9a51be-a231-1707a57b50d6.html

Campbell, T. (2021). Black Lives Matter's Effect on Police Lethal Use-of-Force. SSRN Electronic Journal. https://doi.org/10.2139/ssrn.3767097

Capellan, J. A., \& Lautenschlager, R. (2019). Deconstructing the Ferguson effect: A multilevel mediation analysis of public scrutiny, de-policing, and crime. Journal of Crime and Justice. https://doi.org/10.1080/0735648X.2019.1652921

Capellan, J. A., Lautenschlager, R., \& Silva, J. R. (2020). Deconstructing the Ferguson effect: A multilevel mediation analysis of public scrutiny, de-policing, and crime. Journal of Crime and Justice, 43(2), 125-144. https://doi.org/10.1080/0735648X.2019.1652921

Cassell, P. G., \& Fowles, R. (2018). What Caused the 2016 Chicago Homicide Spike? An Empirical Examination of the 'ACLU Effect' and the Role of Stop and Frisks in Preventing Gun Violence. SSRN Electronic Journal. https://doi.org/10.2139/ssrn.3145287

Childress, S., Amico, C., Chheng, L., Nolan, D., Morando, A., Worth, K., Obeidat, S., Boghani, P., \& Collins, R. (2020). Fixing the Force. In Frontline PBS. PBS. http://apps.frontline.org/fixingtheforce/

Coates, T.-N. (2015). There Is No Ferguson Effect. The Atlantic.

Desmond, M., Kirk, D. S., \& Papachristos, A. V. (2020). Evidence of the effect of police violence on citizen crime reporting. American Sociological Review, 107. https://doi.org/10.1177/0003122419895979

Desmond, M., Papachristos, A. V., \& Kirk, D. S. (2016). Police Violence and Citizen Crime Reporting in the Black Community. American Sociological Review, 81(5), 857-876. https://doi.org/10.1177/0003122416663494 
Devi, T., \& Fryer Jr., R. G. (2020). Policing the Police: The Impact of 'Pattern-or-Practice' Investigations on Crime. In National Bureau of Economic Research (NBER). National Bureau of Economic Research. http://www.nber.org/papers/w27324

Firke, S. (2020). janitor: Simple Tools for Examining and Cleaning Dirty Data (2.0.1).

Fox, J., \& Weisberg, S. (2018). Time-Series Regression and Generalized Least Squares: An Appendix to An R Companion to Applied Regression, third edition. In An R Companion to Applied Regression (3rd ed., Issue January, pp. 1-8).

Gaston, S., Cunningham, J. P., \& Gillezeau, R. (2019). A Ferguson Effect, the drug epidemic, both, or neither? Explaining the 2015 and 2016 U.S. homicide rises by race and ethnicity. Homicide Studies, 23(3), 285-313. https://doi.org/10.1177/1088767919849642

Grolemund, G., \& Wickham, H. (2011). Dates and Times Made Easy with lubridate. Journal of Statistical Software, 40(3), 1-25. https://doi.org/10.18637/jss.v040.i03

Gross, N., \& Mann, M. (2017). Is there a "Ferguson Effect?” Google searches, concern about police violence, and crime in U.S. cities, 2014-2016. Socius: Sociological Research for a Dynamic World, 3, 1-16. https://doi.org/10.1177/2378023117703122

Hawkins, N. G., Sanson-Fisher, R. W., Shakeshaft, A., D’Este, C., \& Green, L. W. (2007). The multiple baseline design for evaluating population-based research. American Journal of Preventive Medicine, 33(2), 162-168.

https://doi.org/10.1016/j.amepre.2007.03.020

Hyndman, R. J., Athanasopolous, G., Bergmeir, C., Caceres, G., Chhay, L., O’Hara-Wild, M., Petropolous, F., Razbash, S., Wang, E., \& Yasmeen, F. (2019). forecast: Forecasting functions for time series and linear models (8.10).

James, N. (2018). Recent Violent Crime Trends in the United States (pp. 1-38). Congressional Research Service. https://fas.org/sgp/crs/misc/R45236.pdf 
Jebb, A. T., Tay, L., Wang, W., \& Huang, Q. (2015). Time series analysis for psychological research: Examining and forecasting change. Frontiers in Psychology, 6. https://doi.org/10.3389/fpsyg.2015.00727

Kaplan, J. (2020). Jacob Kaplan's Concatenated Files: Uniform Crime Reporting Program Data: Offenses Known and Clearances by Arrest, 1960-2019. Inter-University Consortium for Political and Social Research; Inter-university Consortium for Political and Social Research. https://doi.org/10.3886/E100707V15

Kapustin, M., Ludwig, J., Punkay, M., Smith, K., Speigel, L., \& Welgus, D. (2017). Gun Violence Gun Violence in Chicago, 2016. University of Chicago Crime Labs. https://urbanlabs.uchicago.edu/attachments/store/2435a5d4658e2ca19f4f225b810ce0d bdb9231cbdb8d702e784087469ee3/UChicagoCrimeLab+Gun+Violence+in+Chicago +2016.pdf

Kassambara, A. (2019). ggpubr: 'ggplot2’ Based Publication Ready Plots. (0.2.4).

Kirk, D. S., \& Papachristos, A. V. (2011). Cultural mechanisms and the persistence of neighborhood violence. American Journal of Sociology, 116(4), 1190-1233. https://doi.org/10.1086/655754

Kossmeier, M., Tran, U. S., \& Voracek, M. (2019). metaviz: Forest Plots, Funnel Plots, and Visual Funnel Plot Inference for Meta-Analysis (0.3.0).

Lane, T. J. (2019). Police-involved deaths and homicides-Data and analysis files [Repository]. Bridges. https://doi.org/10.26180/5db160fa6a50b

Lauritsen, J. L., \& Lentz, T. S. (2019). National and Local Trends in Serious Violence, Firearm Victimization, and Homicide. Homicide Studies, 23(3), 243-261. https://doi.org/10.1177/1088767919848665

Leovy, J. (2015). Ghettoside: Investigating a Homicide Epidemic. Spiegel \& Grau. 
Louisville Open Data. (2020). Crime Reports. https://data.louisvilleky.gov/dataset/crimereports

Lüdecke, D., Makowski, D., Waggoner, P., \& Ben-Shachar, M. S. (2019). see: Visualisation Toolbox for 'easystats' and Extra Geoms, Themes, and Color Palettes for 'ggplot2'. (0.2.0).

Mac Donald, H. (2017). The War on Cops: How the New Attack on Law and Order Makes Everyone Less Safe. Encounter Books.

McMillan Cottom, T. (2015, September 17). Race Is Always the Issue. The Atlantic. https://www.theatlantic.com/politics/archive/2015/09/race-is-always-theissue/405295/

Mock, B. (2015). Busting the Myth of 'The Ferguson Effect'. CityLab. https://www.citylab.com/equity/2015/06/busting-the-myth-of-the-fergusoneffect/396068/

Morgan, R. E., \& Truman, J. L. (2018). Criminal Victimization, 2017. In Bureau of Justice (NCJ 252472). United States Department of Justice. https://www.bjs.gov/content/pub/pdf/cv17.pdf

Morgan, S. L. (2016). Fall 2016 Update for Ferguson, Gray, and Davis: An Analysis of Recorded Crime Incidents and Arrests in Baltimore City, March 2010 through October 2016. Johns Hopkins University. http://socweb.soc.jhu.edu/faculty/morgan/papers/MorganPally2016FallUpdate.pdf Morgan, S. L., \& Pally, J. A. (2015). Ferguson, Gray, and Davis: An Analysis of Recorded Crime Incidents and Arrests in Baltimore City, March 2010 through December 2015. Johns Hopkins University. http://socweb.soc.jhu.edu/faculty/morgan/papers/MorganPally2016.pdf 
O'Flaherty, B., \& Sethi, R. (2019). Shadows of Doubt: Stereotypes, Crime, and the Pursuit of Justice. Harvard University Press.

Pinheiro, J., Bates, D., DebRoy, S., Sarkar, D., \& R Core Team. (2020). nlme: Linear and Nonlinear Mixed Effects Models (R package version 3.1-149).

Pyrooz, D. C., Decker, S. H., Wolfe, S. E., \& Shjarback, J. A. (2016). Was there a Ferguson Effect on crime rates in large U.S. cities? Journal of Criminal Justice, 46, 1-8. https://doi.org/10.1016/j.jcrimjus.2016.01.001

R Core Team. (2020). R: A language and environment for statistical computing (4.0.3). R Foundation for Statistical Computing.

Raleigh Open Data. (2020). Raleigh Police Incidents (NIBRS). http://dataral.opendata.arcgis.com/datasets/raleigh-police-incidents-nibrs?geometry=80.029\%2C35.408\%2C-77.219\%2C36.188\&selectedAttribute=reported_year

Rosenfeld, R. (2015). Was There a "Ferguson Effect" on Crime in St. Louis? In Sentencing Project (pp. 1-4). The Sentencing Project. https://sentencingproject.org/wpcontent/uploads/2015/09/Ferguson-Effect.pdf

Rosenfeld, R. (2016). Documenting and Explaining the 2015 Homicide Rise: Research Directions (pp. 1-31). National Institute of Justice. https://www.ncjrs.gov/pdffiles1/nij/249895.pdf

Rosenfeld, R. (2018). Studying crime trends: Normal science and exogenous shocks. Criminology, 56(1), 5-26. https://doi.org/10.1111/1745-9125.12170

Rosenfeld, R., \& Fox, J. A. (2019). Anatomy of the Homicide Rise. Homicide Studies, 23(3), 202-224. https://doi.org/10.1177/1088767919848821

Rosenfeld, R., Gaston, S., Spivak, H., \& Irazola, S. (2017). Assessing and Responding to the Recent Homicide Rise in the United States (NCJ 251067; p. 46). United States Department of Justice. https://www.ojp.gov/pdffiles1/nij/251067.pdf 
Rosenfeld, R., \& Lopez, E. (2020). Pandemic, Social Unrest, and Crime in U.S. Cities (p. 20). Council on Criminal Justice.

Rosenfeld, R., \& Wallman, J. (2019). Did de-policing cause the increase in homicide rates? Criminology and Public Policy, 18(1), 51-75. https://doi.org/10.1111/17459133.12414

RStudio Team. (2020). RStudio: Integrated Development for $R$ (1.3.1073). RStudio, Inc. Rushin, S., \& Edwards, G. (2016). De-Policing. Cornell Law Review, 102, 721-782. Sampson, R. J., \& Bartusch, D. J. (1998). Legal cynicism and (subcultural?) tolerance of deviance: The neighborhood context of racial differences. Law \& Society Review, 32(4), 777. https://doi.org/10.2307/827739

Shadish, W. R., Cook, T. D., \& Campbell, D. T. (2002). Experimental and QuasiExperimental Designs for Generalized Causal Inference. Houghton Mifflin.

Shjarback, J. A., Pyrooz, D. C., Wolfe, S. E., \& Decker, S. H. (2017). De-policing and crime in the wake of Ferguson: Racialized changes in the quantity and quality of policing among Missouri police departments. Journal of Criminal Justice, 50, 42-52. https://doi.org/10.1016/j.jcrimjus.2017.04.003

Skoy, E. (2020). Black Lives Matter Protests, Fatal Police Interactions, and Crime. Contemporary Economic Policy, 1-12. https://doi.org/10.1111/coep.12508

Tate, J., Jenkins, J., \& Rich, S. (2020). Fatal Force. The Washington Post. https://www.washingtonpost.com/graphics/investigations/police-shootings-database/

United States Census Bureau. (2010). Modified Race Data 2010. https://www.census.gov/data/datasets/2010/demo/popest/modified-race-data2010.html

United States Census Bureau. (2014). State and County Estimates for 2014. https://www.census.gov/data/datasets/2014/demo/saipe/2014-state-and-county.html 
United States Census Bureau. (2020). Annual Estimates of the Resident Population for Incorporated Places of 50,000 or More, Ranked by July 1, 2019 Population: April 1, 2010 to July 1, 2019. City and Town Population Totals: 2010-2019. https://www.census.gov/data/tables/time-series/demo/popest/2010s-total-cities-andtowns.html

United States Department of Justice. (2015). Department of Justice Report Regarding the Criminal Investigation Into the Shooting Death of Michael Brown by Ferguson, Missouri Police Officer Darren Wilson (pp. 1-86). Department of Justice. https://permanent.access.gpo.gov/gpo55759/doj_report_on_shooting_of_michael_bro wn.pdf

United States Department of Justice Civil Rights Division. (2015). Investigation of the Ferguson Police Department. Department of Justice.

United States Department of Justice, \& Federal Bureau of Investigation. (2013). Summary Reporting System (SRS) User Manual.

Vandegrift, D., \& Connor, B. J. (2020). The Effect of Police Use of Lethal Force on Murder Levels in American Cities Before and After Ferguson. Journal of Quantitative Criminology, 36(1), 235-261. https://doi.org/10.1007/s10940-019-09429-6

Viechtbauer, W. (2010). Conducting meta-analyses in R with the metafor package. Journal of Statistical Software, 36(3), 1-48.

Wickham, H., Averick, M., Bryan, J., Chang, W., McGowan, L., François, R., Grolemund, G., Hayes, A., Henry, L., Hester, J., Kuhn, M., Pedersen, T., Miller, E., Bache, S., Müller, K., Ooms, J., Robinson, D., Seidel, D., Spinu, V., ... Yutani, H. (2019). Welcome to the Tidyverse. Journal of Open Source Software, 4(43), 1686. https://doi.org/10.21105/joss.01686

Wickham, H., \& Seidel, D. (2019). scales: Scale Functions for Visualization (1.1.0). 
Williamson, V., Trump, K. S., \& Einstein, K. L. (2018). Black Lives Matter: Evidence that Police-Caused Deaths Predict Protest Activity. Perspectives on Politics, 16(2), 400415. https://doi.org/10.1017/S1537592717004273

Zeileis, A., \& Grothendieck, G. (2005). zoo: S3 Infrastructure for Regular and Irregular Time Series. Journal of Statistical Software, 14(6), 1-27.

https://doi.org/10.1017/CBO9781107415324.004 

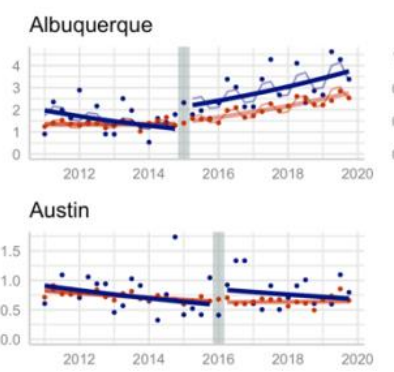

Charleston-North Charleston
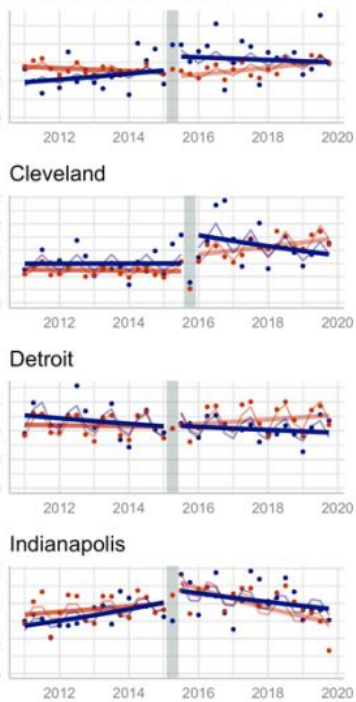

Memphis

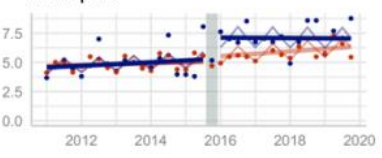

New York
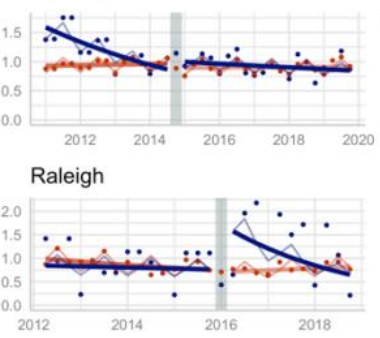

San Francisco
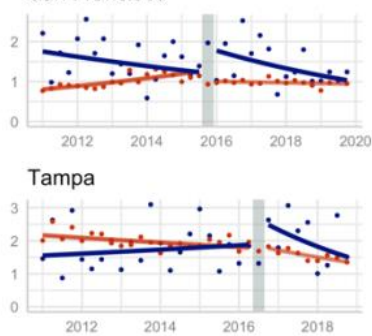

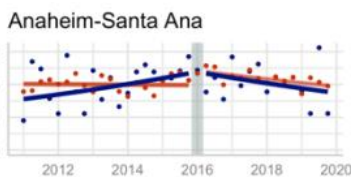

Bakersfield

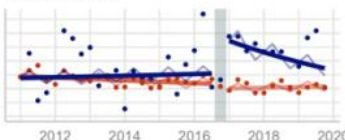

Charlotte

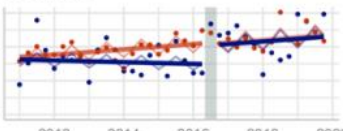

Columbus

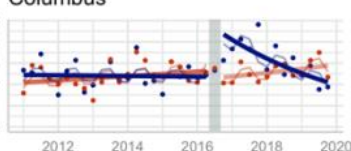

Durham

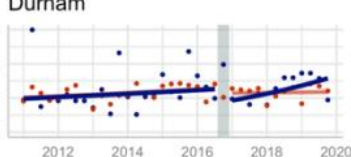

Long Beach

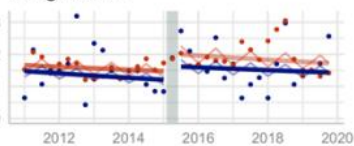

Milwaukee

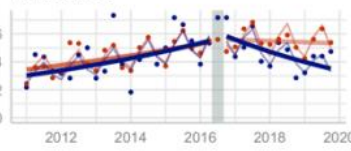

Oakland

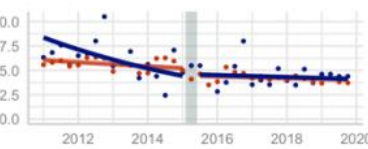

Sacramento

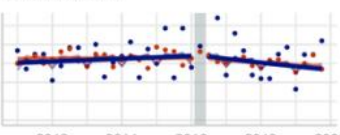

Seattle

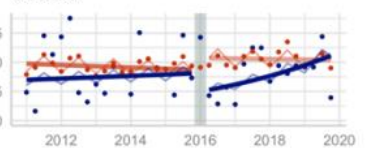

Tulsa

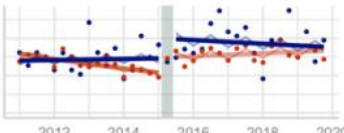

Atlanta

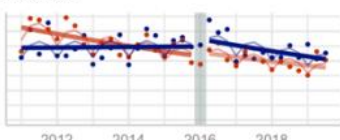

Baltimore

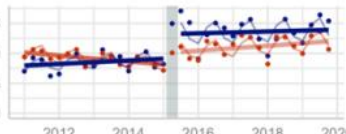

Chicago

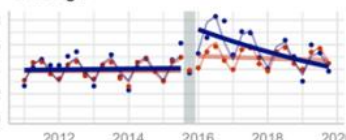

Dallas-Fort Worth-Arlington

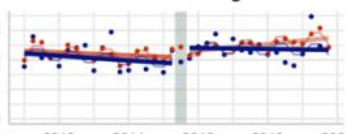

Fresno

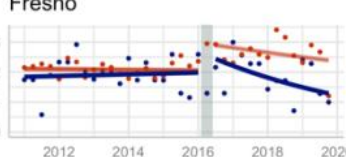

Los Angeles

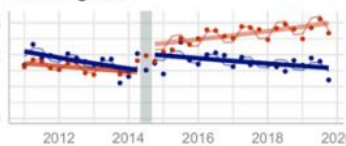

Minneapolis-St Paul

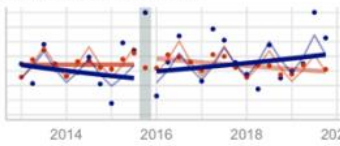

Philadelphia

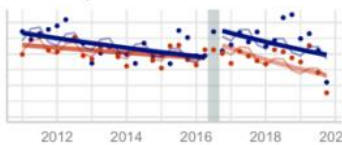

San Antonio

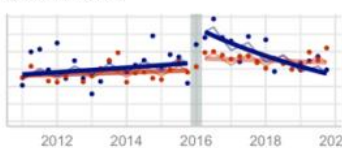

St Louis

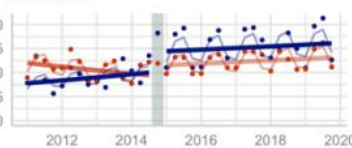

Washington DC

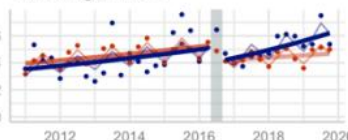

Aurora

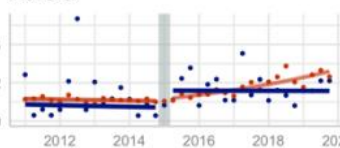

Baton Rouge

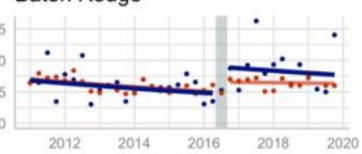

Cincinnati

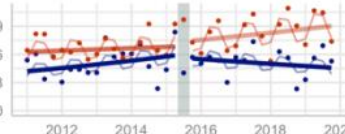

Detroit

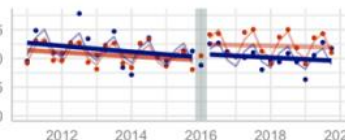

Houston

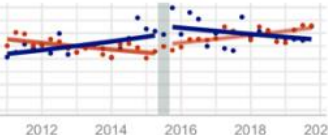

Louisville

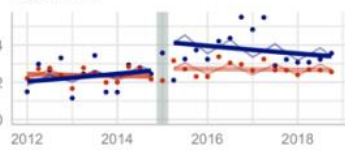

New Orleans

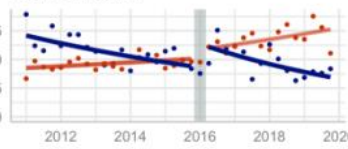

Greater Phoenix

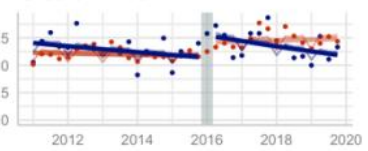

San Diego

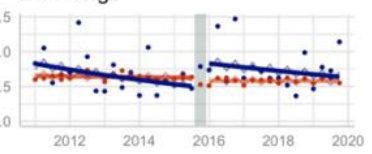

Stockton

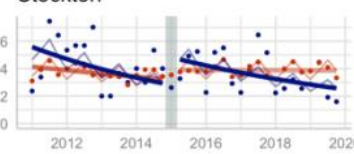

Wichita

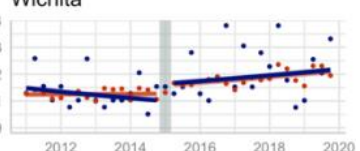

Supplementary figure 1. Individually-plotted interrupted time series models for each of the 44 city-events analysed 


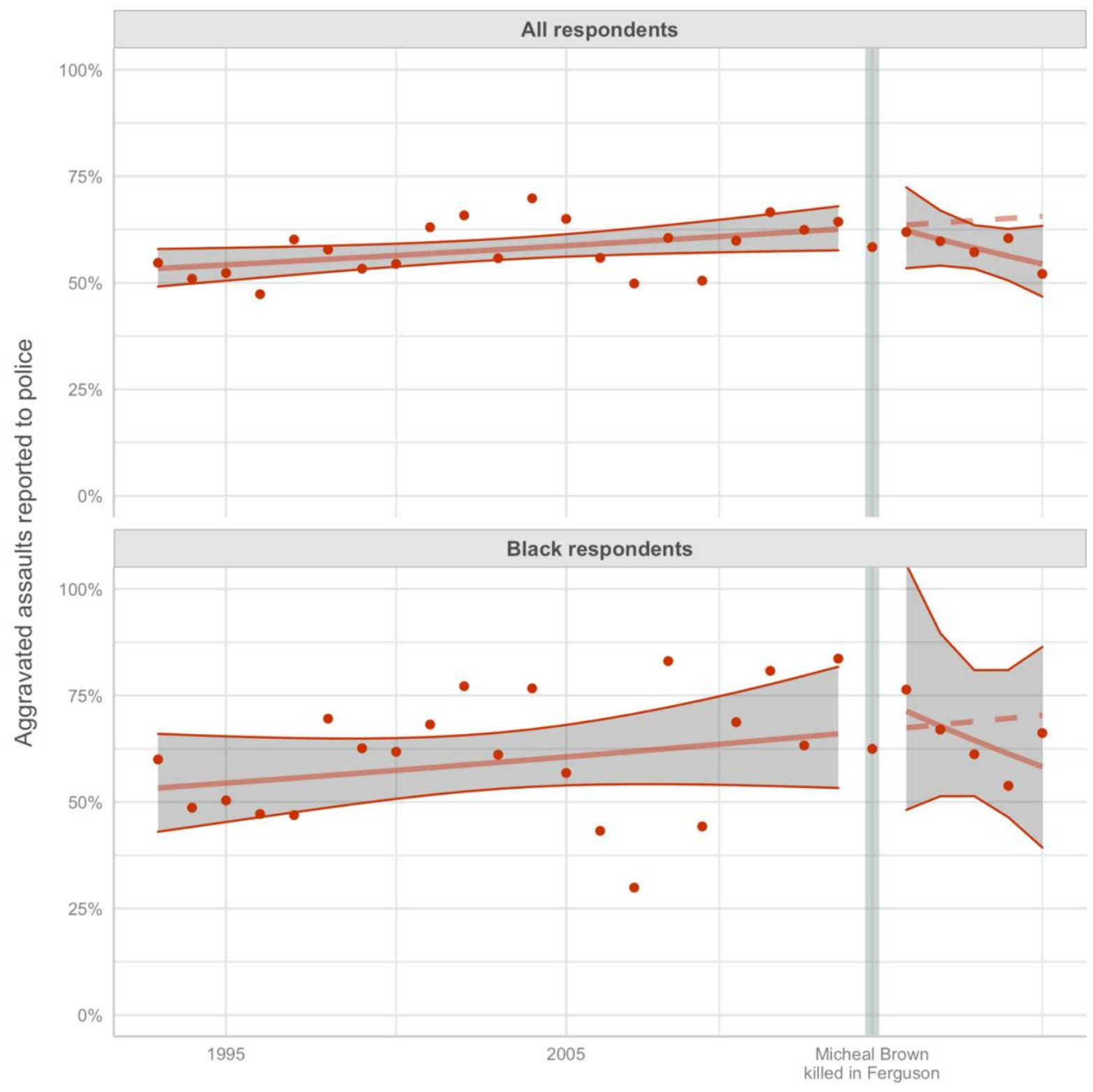

Supplementary figure 2. Interrupted time series modelling of the proportion of aggravated assaults reported to police based on responses to the National Crime Victimization Survey (Bureau of Justice Statistics, 2019) 
Supplementary table 1. Results of individual city-event interrupted time series models of the effects of protested police-involved deaths on homicide and aggravated assault

\begin{tabular}{|c|c|c|c|c|c|c|c|c|c|c|}
\hline City & Victim name & $\begin{array}{l}\text { Year/ } \\
\text { qtr }\end{array}$ & Acute homicide & $\begin{array}{l}\text { p-value (acute } \\
\text { homicide) }\end{array}$ & $\begin{array}{l}\text { Gradual } \\
\text { homicide }\end{array}$ & $\begin{array}{l}\text { p-value (gradual } \\
\text { homicide) }\end{array}$ & Acute assault & $\begin{array}{l}\mathrm{p} \text {-value (acute } \\
\text { assault) }\end{array}$ & Gradual assault & $\begin{array}{l}\mathrm{p} \text {-value (gradual } \\
\text { assault) }\end{array}$ \\
\hline Albuquerque & $\begin{array}{l}\text { John Edward } \\
\text { O'Keefe }\end{array}$ & $\begin{array}{l}2015 \\
\text { Q1 }\end{array}$ & $\begin{array}{l}59.3 \% \text { ( } 47.7 \% \text { to } \\
70.9 \%)\end{array}$ & $<0.001$ & $\begin{array}{l}6.5 \%(5.2 \% \text { to } \\
7.8 \%)\end{array}$ & $<0.001$ & $\begin{array}{l}-55.2 \%(-71.6 \% \text { to } \\
-38.9 \%)\end{array}$ & $<0.001$ & $\begin{array}{l}<0.001(-4.9 \% \\
\text { to }-1.4 \%)\end{array}$ & $<0.001$ \\
\hline $\begin{array}{l}\text { Anaheim-Santa } \\
\text { Ana }\end{array}$ & $\begin{array}{l}\text { Gustavo } \\
\text { Najera }\end{array}$ & $\begin{array}{l}2016 \\
\text { Q1 }\end{array}$ & $\begin{array}{l}3.8 \%(-13.7 \% \text { to } \\
21.2 \%)\end{array}$ & 0.58 & $\begin{array}{l}-4.1 \%(-5.8 \% \text { to } \\
-2.3 \%)\end{array}$ & $<0.001$ & $\begin{array}{l}17.7 \%(-7.0 \% \text { to } \\
42.4 \%)\end{array}$ & 0.07 & $\begin{array}{l}0.070(0.3 \% \text { to } \\
5.2 \%)\end{array}$ & 0.005 \\
\hline Atlanta & Anthony Hill & $\begin{array}{l}2016 \\
\text { Q1 }\end{array}$ & $\begin{array}{l}11.7 \%(-12.6 \% \text { to } \\
36.1 \%)\end{array}$ & 0.22 & $\begin{array}{l}-2.1 \%(-4.6 \% \text { to } \\
0.4 \%)\end{array}$ & 0.031 & $\begin{array}{l}-5.8 \%(-40.2 \% \text { to } \\
28.6 \%)\end{array}$ & 0.667 & $\begin{array}{l}0.667(-1.3 \% \text { to } \\
5.7 \%)\end{array}$ & 0.113 \\
\hline Aurora & $\begin{array}{l}\text { Naeschylus } \\
\text { Vinzant }\end{array}$ & $\begin{array}{l}2015 \\
\text { Q1 }\end{array}$ & $\begin{array}{l}79.7 \% \text { ( } 0.8 \% \text { to } \\
158.6 \% \text { ) }\end{array}$ & 0.012 & $\begin{array}{l}1.2 \%(-6.5 \% \text { to } \\
8.9 \%)\end{array}$ & 0.683 & $\begin{array}{l}-74.5 \%(-186.0 \% \\
\text { to } 37.0 \%)\end{array}$ & 0.09 & $\begin{array}{l}0.090 \text { ( }-7.2 \% \text { to } \\
14.6 \%)\end{array}$ & 0.383 \\
\hline Austin & David Joseph & $\begin{array}{l}2016 \\
\text { Q1 }\end{array}$ & $\begin{array}{l}36.6 \% \text { ( } 21.4 \% \text { to } \\
51.8 \%)\end{array}$ & $<0.001$ & $\begin{array}{l}0.9 \%(-0.8 \% \text { to } \\
2.5 \%)\end{array}$ & 0.184 & $\begin{array}{l}-38.9 \%(-60.4 \% \text { to } \\
-17.4 \%)\end{array}$ & $<0.001$ & $\begin{array}{l}<0.001(-1.8 \% \\
\text { to } 2.9 \%)\end{array}$ & 0.541 \\
\hline Bakersfield & $\begin{array}{l}\text { Francisco } \\
\text { Serna }\end{array}$ & $\begin{array}{l}2016 \\
Q 4\end{array}$ & $\begin{array}{l}65.0 \%(-12.6 \% \text { to } \\
142.7 \%)\end{array}$ & 0.035 & $\begin{array}{l}-4.6 \%(-13.3 \% \\
\text { to } 4.1 \%)\end{array}$ & 0.177 & $\begin{array}{l}-81.8 \%(-191.5 \% \\
\text { to } 27.8 \%)\end{array}$ & 0.059 & $\begin{array}{l}0.059 \text { ( }-6.0 \% \text { to } \\
18.5 \%)\end{array}$ & 0.196 \\
\hline Baltimore & Freddie Gray & $\begin{array}{l}2015 \\
\text { Q2 }\end{array}$ & $\begin{array}{l}37.0 \% \text { ( } 19.4 \% \text { to } \\
54.7 \% \text { ) }\end{array}$ & $<0.001$ & $\begin{array}{l}-0.6 \%(-2.2 \% \text { to } \\
1.1 \%)\end{array}$ & 0.39 & $\begin{array}{l}-16.1 \%(-41.0 \% \text { to } \\
8.8 \%)\end{array}$ & 0.1 & $\begin{array}{l}0.100 \text { ( } 0.5 \% \text { to } \\
5.2 \%)\end{array}$ & 0.003 \\
\hline Baton Rouge & Alton Sterling & $\begin{array}{l}2016 \\
\text { Q3 }\end{array}$ & $\begin{array}{l}64.4 \% \text { ( } 9.4 \% \text { to } \\
119.3 \%)\end{array}$ & 0.004 & $\begin{array}{l}0.6 \%(-5.2 \% \text { to } \\
6.4 \%)\end{array}$ & 0.795 & $\begin{array}{l}-36.0 \%(-113.8 \% \\
\text { to } 41.7 \%)\end{array}$ & 0.237 & $\begin{array}{l}0.237(-7.4 \% \text { to } \\
9.0 \%)\end{array}$ & 0.808 \\
\hline $\begin{array}{l}\text { Charleston-North } \\
\text { Charleston }\end{array}$ & Walter Scott & $\begin{array}{l}2015 \\
\text { Q2 }\end{array}$ & $\begin{array}{l}26.8 \% \text { ( } 8.4 \% \text { to } \\
45.1 \% \text { ) }\end{array}$ & $<0.001$ & $\begin{array}{l}-2.4 \%(-4.1 \% \text { to } \\
-0.6 \%)\end{array}$ & $<0.001$ & $\begin{array}{l}-38.8 \%(-64.7 \% \text { to } \\
-12.8 \%)\end{array}$ & $<0.001$ & $\begin{array}{l}<0.001(2.5 \% \\
\text { to } 7.3 \%)\end{array}$ & $<0.001$ \\
\hline Charlotte & $\begin{array}{l}\text { Keith Lamont } \\
\text { Scott }\end{array}$ & $\begin{array}{l}2016 \\
\text { Q3 }\end{array}$ & $\begin{array}{l}30.7 \%(-10.3 \% \text { to } \\
71.8 \%)\end{array}$ & 0.058 & $\begin{array}{l}1.3 \%(-3.0 \% \text { to } \\
5.6 \%)\end{array}$ & 0.444 & $\begin{array}{l}-32.3 \%(-90.3 \% \text { to } \\
25.6 \%)\end{array}$ & 0.156 & $\begin{array}{l}0.156(-7.5 \% \text { to } \\
4.7 \%)\end{array}$ & 0.559 \\
\hline Chicago & $\begin{array}{l}\text { Laquan } \\
\text { McDonald }\end{array}$ & $\begin{array}{l}2015 \\
Q 4\end{array}$ & $\begin{array}{l}64.2 \% \text { ( } 39.7 \% \text { to } \\
88.7 \% \text { ) }\end{array}$ & $<0.001$ & $\begin{array}{l}-3.8 \%(-6.1 \% \text { to } \\
-1.5 \%)\end{array}$ & $<0.001$ & $\begin{array}{l}-37.4 \%(-71.8 \% \text { to } \\
-3.0 \%)\end{array}$ & 0.007 & $\begin{array}{l}0.007 \text { ( } 0.1 \% \text { to } \\
6.5 \%)\end{array}$ & 0.011 \\
\hline Cincinnati & $\begin{array}{l}\text { Samuel } \\
\text { DuBose }\end{array}$ & $\begin{array}{l}2015 \\
\text { Q3 }\end{array}$ & $\begin{array}{l}-3.2 \% \text { ( }-10.7 \% \text { to } \\
4.4 \%)\end{array}$ & 0.284 & $\begin{array}{l}-3.2 \%(-4.3 \% \text { to } \\
-2.1 \%)\end{array}$ & $<0.001$ & $\begin{array}{l}9.6 \%(-1.0 \% \text { to } \\
20.1 \%)\end{array}$ & 0.023 & $\begin{array}{l}0.023 \text { ( } 2.3 \% \text { to } \\
5.4 \%)\end{array}$ & $<0.001$ \\
\hline Cleveland & Tamir Rice & $\begin{array}{l}2015 \\
\text { Q4 }\end{array}$ & $\begin{array}{l}58.3 \% \text { ( } 19.8 \% \text { to } \\
96.9 \%)\end{array}$ & $<0.001$ & $\begin{array}{l}-2.3 \%(-5.9 \% \text { to } \\
1.4 \%)\end{array}$ & 0.116 & $\begin{array}{l}-19.3 \%(-73.6 \% \text { to } \\
35.1 \%)\end{array}$ & 0.365 & $\begin{array}{l}0.365 \text { ( }-0.8 \% \text { to } \\
9.5 \%)\end{array}$ & 0.034 \\
\hline Columbus & Henry Green & $\begin{array}{l}2016 \\
Q 3\end{array}$ & $\begin{array}{l}73.4 \% \text { ( } 36.0 \% \text { to } \\
110.9 \% \text { ) }\end{array}$ & $<0.001$ & $\begin{array}{l}-5.9 \%(-9.9 \% \text { to } \\
-2.0 \%)\end{array}$ & $<0.001$ & $\begin{array}{l}-89.2 \%(-142.1 \% \\
\text { to }-36.3 \%)\end{array}$ & $<0.001$ & $\begin{array}{l}<0.001(1.0 \% \\
\text { to } 12.2 \%)\end{array}$ & 0.003 \\
\hline
\end{tabular}




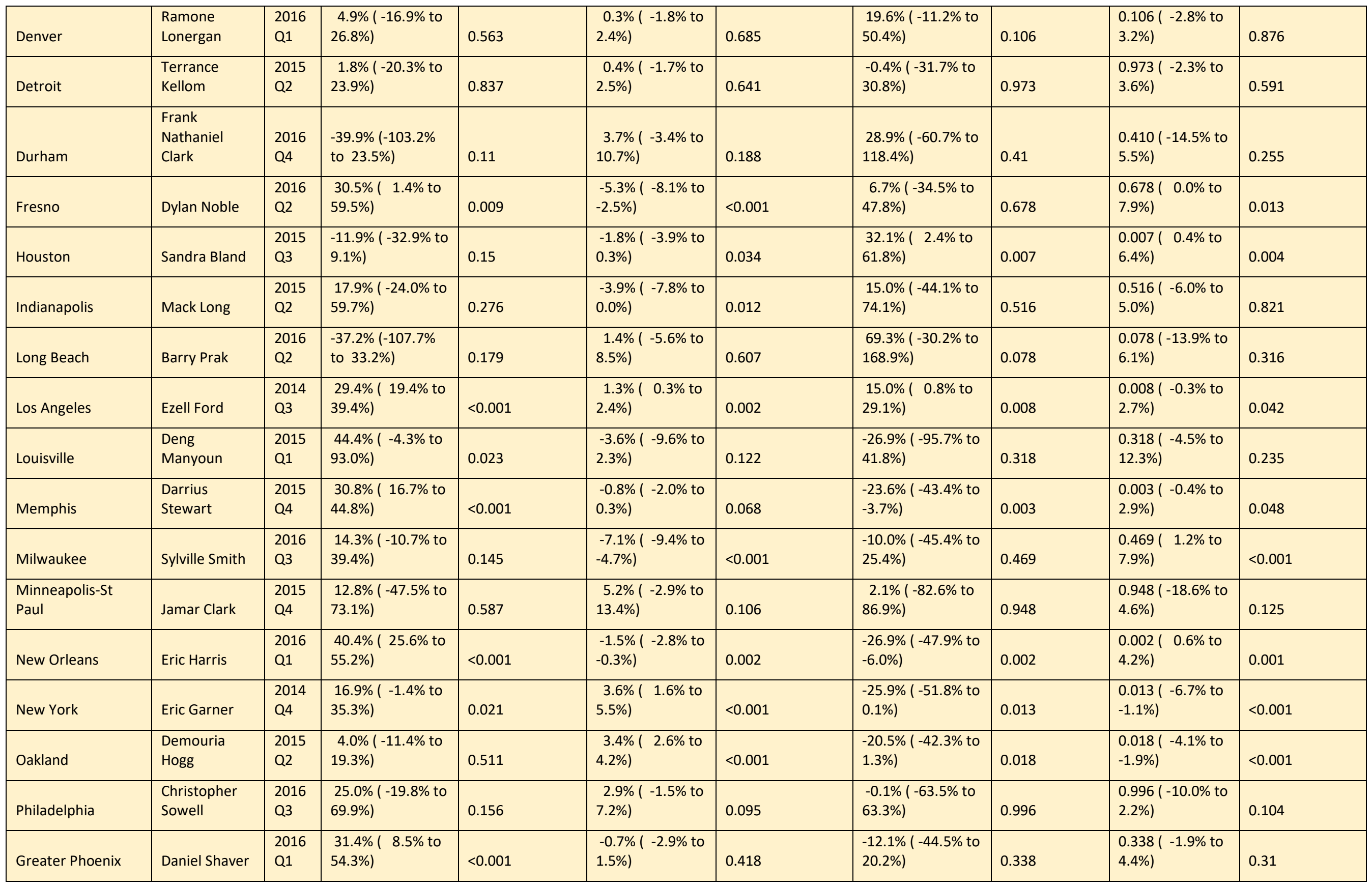




\begin{tabular}{|c|c|c|c|c|c|c|c|c|c|c|}
\hline Raleigh & Akiel Denkins & $\begin{array}{l}2016 \\
\text { Q1 }\end{array}$ & $\begin{array}{l}89.9 \% \text { ( }-10.5 \% \text { to } \\
190.2 \%)\end{array}$ & 0.026 & $\begin{array}{l}-8.1 \%(-20.9 \% \\
\text { to } 4.7 \%)\end{array}$ & 0.11 & $\begin{array}{l}-97.9 \%(-239.8 \% \\
\text { to } 44.1 \%)\end{array}$ & 0.083 & $\begin{array}{l}0.083(-6.7 \% \text { to } \\
29.5 \%)\end{array}$ & 0.111 \\
\hline Sacramento & $\begin{array}{l}\text { Dazion } \\
\text { Flenaugh }\end{array}$ & $\begin{array}{l}2016 \\
Q 2\end{array}$ & $\begin{array}{l}-6.5 \%(-24.2 \% \text { to } \\
11.1 \%)\end{array}$ & 0.343 & $\begin{array}{l}-1.7 \%(-3.7 \% \text { to } \\
0.3 \%)\end{array}$ & 0.032 & $\begin{array}{l}2.7 \%(-22.2 \% \text { to } \\
27.6 \%)\end{array}$ & 0.782 & $\begin{array}{l}0.782(-2.0 \% \text { to } \\
3.6 \%)\end{array}$ & 0.465 \\
\hline San Antonio & Antronie Scott & $\begin{array}{l}2016 \\
\text { Q1 }\end{array}$ & $\begin{array}{l}52.2 \% \text { ( } 36.2 \% \text { to } \\
68.2 \% \text { ) }\end{array}$ & $<0.001$ & $\begin{array}{l}-5.6 \%(-7.0 \% \text { to } \\
-4.2 \%)\end{array}$ & $<0.001$ & $\begin{array}{l}-30.1 \%(-52.7 \% \text { to } \\
-7.5 \%)\end{array}$ & 0.001 & $\begin{array}{l}0.001 \text { ( } 2.7 \% \text { to } \\
6.5 \%)\end{array}$ & $<0.001$ \\
\hline San Diego & $\begin{array}{l}\text { Lamontez } \\
\text { Jones }\end{array}$ & $\begin{array}{l}2015 \\
Q 4\end{array}$ & $\begin{array}{l}53.5 \% \text { ( } 8.5 \% \text { to } \\
98.6 \%)\end{array}$ & 0.003 & $\begin{array}{l}1.0 \%(-3.3 \% \text { to } \\
5.3 \%)\end{array}$ & 0.542 & $\begin{array}{l}-60.6 \%(-124.3 \% \\
\text { to } 3.1 \%)\end{array}$ & 0.017 & $\begin{array}{l}0.017(-6.9 \% \text { to } \\
5.2 \%)\end{array}$ & 0.727 \\
\hline San Francisco & Mario Woods & $\begin{array}{l}2015 \\
Q 4\end{array}$ & $\begin{array}{l}43.3 \% \text { ( } 15.3 \% \text { to } \\
71.4 \%)\end{array}$ & $<0.001$ & $\begin{array}{l}-1.7 \%(-3.9 \% \text { to } \\
0.6 \%)\end{array}$ & 0.063 & $\begin{array}{l}-65.0 \%(-104.7 \% \\
\text { to }-25.4 \%)\end{array}$ & $<0.001$ & $\begin{array}{l}<0.001(-4.4 \% \\
\text { to } 2.0 \%)\end{array}$ & 0.324 \\
\hline St Louis & $\begin{array}{l}\text { Michael } \\
\text { Brown }\end{array}$ & $\begin{array}{l}2014 \\
Q 4\end{array}$ & $\begin{array}{l}35.5 \% \text { ( } 23.7 \% \text { to } \\
47.2 \%)\end{array}$ & $<0.001$ & $\begin{array}{l}-1.2 \%(-2.4 \% \text { to } \\
-0.1 \%)\end{array}$ & 0.008 & $\begin{array}{l}-16.8 \%(-33.4 \% \text { to } \\
-0.3 \%)\end{array}$ & 0.011 & $\begin{array}{l}0.011 \text { ( } 2.0 \% \text { to } \\
5.3 \%)\end{array}$ & $<0.001$ \\
\hline Seattle & Che Taylor & $\begin{array}{l}2016 \\
Q 1\end{array}$ & $\begin{array}{l}-53.7 \%(-88.9 \% \text { to } \\
-18.5 \%)\end{array}$ & $<0.001$ & $\begin{array}{l}4.6 \% \text { ( } 1.6 \% \text { to } \\
7.5 \%)\end{array}$ & $<0.001$ & $\begin{array}{l}74.5 \% \text { ( } 24.8 \% \text { to } \\
124.2 \%)\end{array}$ & $<0.001$ & $\begin{array}{l}<0.001(-8.2 \% \\
\text { to }-0.2 \%)\end{array}$ & 0.01 \\
\hline Stockton & Matautu Nuu & $\begin{array}{l}2015 \\
\text { Q1 }\end{array}$ & $\begin{array}{l}53.0 \% \text { ( } 43.2 \% \text { to } \\
62.8 \%)\end{array}$ & $<0.001$ & $\begin{array}{l}1.0 \% \text { ( }-0.6 \% \text { to } \\
2.5 \%)\end{array}$ & 0.106 & $\begin{array}{l}-34.6 \% \text { ( }-48.4 \% \text { to } \\
-20.7 \%)\end{array}$ & $<0.001$ & $\begin{array}{l}<0.001(-1.5 \% \\
\text { to } 2.7 \%)\end{array}$ & 0.482 \\
\hline Tampa & $\begin{array}{l}\text { Levonia } \\
\text { Riggins }\end{array}$ & $\begin{array}{l}2016 \\
\text { Q3 }\end{array}$ & $\begin{array}{l}40.2 \% \text { ( } 2.2 \% \text { to } \\
78.3 \%)\end{array}$ & 0.009 & $\begin{array}{l}-7.1 \%(-12.9 \% \\
\text { to }-1.3 \%)\end{array}$ & 0.003 & $\begin{array}{l}-34.6 \%(-88.4 \% \text { to } \\
19.1 \%)\end{array}$ & 0.103 & $\begin{array}{l}0.103 \text { ( }-3.5 \% \text { to } \\
12.9 \%)\end{array}$ & 0.149 \\
\hline Tulsa & Eric Harris & $\begin{array}{l}2015 \\
\text { Q2 }\end{array}$ & $\begin{array}{l}\text { 31.7\% ( } 9.4 \% \text { to } \\
53.9 \%)\end{array}$ & $<0.001$ & $\begin{array}{l}-0.9 \%(-3.0 \% \text { to } \\
1.1 \%)\end{array}$ & 0.25 & $\begin{array}{l}0.2 \%(-31.3 \% \text { to } \\
31.6 \%)\end{array}$ & 0.99 & $\begin{array}{l}0.990 \text { ( } 1.0 \% \text { to } \\
6.9 \%)\end{array}$ & $<0.001$ \\
\hline Washington DC & $\begin{array}{l}\text { Terrence } \\
\text { Sterling }\end{array}$ & $\begin{array}{l}2016 \\
\text { Q3 }\end{array}$ & $\begin{array}{l}-24.8 \%(-56.4 \% \text { to } \\
6.8 \%)\end{array}$ & 0.047 & $\begin{array}{l}1.5 \% \text { ( }-1.8 \% \text { to } \\
4.8 \%)\end{array}$ & 0.254 & $\begin{array}{l}0.2 \%(-44.4 \% \text { to } \\
44.8 \%)\end{array}$ & 0.99 & $\begin{array}{l}0.990 \text { ( }-6.6 \% \text { to } \\
2.8 \%)\end{array}$ & 0.293 \\
\hline Wichita & $\begin{array}{l}\text { John Paul } \\
\text { Quintero }\end{array}$ & $\begin{array}{l}2015 \\
\text { Q1 }\end{array}$ & $\begin{array}{l}45.5 \% \text { ( }-15.8 \% \text { to } \\
106.7 \%)\end{array}$ & 0.061 & $\begin{array}{l}3.9 \%(-2.1 \% \text { to } \\
9.8 \%)\end{array}$ & 0.101 & $\begin{array}{l}-25.3 \%(-111.9 \% \\
\text { to } 61.4 \%)\end{array}$ & 0.456 & $\begin{array}{l}0.456(-11.0 \% \text { to } \\
5.9 \%)\end{array}$ & 0.445 \\
\hline Summary & NA & NA & $\begin{array}{l}26.1 \% \text { ( } 15.3 \% \text { to } \\
36.8 \% \text { ) }\end{array}$ & $<0.001$ & $\begin{array}{l}-0.7 \%(-2.0 \% \text { to } \\
0.5 \%)\end{array}$ & 0.132 & $\begin{array}{l}-15.2 \%(-26.7 \% \text { to } \\
-3.6 \%)\end{array}$ & 0.001 & $\begin{array}{l}0.001 \text { ( } 0.1 \% \text { to } \\
2.4 \%)\end{array}$ & 0.006 \\
\hline
\end{tabular}


Supplementary table 2. Results of individual city-event interrupted time series models of the effects of protested police-involved deaths on homicide and aggravated assault (absolute effect sizes)

\begin{tabular}{|c|c|c|c|c|c|c|c|c|c|c|}
\hline City & Victim name & $\begin{array}{l}\text { Year/ } \\
\text { qtr }\end{array}$ & Acute homicide & $\begin{array}{l}\text { p-value (acute } \\
\text { homicide) }\end{array}$ & Gradual homicide & $\begin{array}{l}\text { p-value (gradual } \\
\text { homicide) }\end{array}$ & Acute assault & $\begin{array}{l}\text { p-value (acute } \\
\text { assault) }\end{array}$ & Gradual assault & $\begin{array}{l}\mathrm{p} \text {-value } \\
\text { (gradual } \\
\text { assault) }\end{array}$ \\
\hline Albuquerque & $\begin{array}{l}\text { John Edward } \\
\text { O'Keefe }\end{array}$ & $\begin{array}{l}2015 \\
\text { Q1 }\end{array}$ & $\begin{array}{l}63.9 \% \text { ( } 15.9 \% \text { to } \\
112.0 \%)\end{array}$ & 0.001 & $\begin{array}{l}14.1 \% \text { ( } 9.9 \% \text { to } \\
18.2 \%)\end{array}$ & $<0.001$ & $\begin{array}{l}-69.7 \%(-137.3 \% \\
\text { to }-2.1 \%)\end{array}$ & 0.010 & $\begin{array}{l}0.010(-13.5 \% \text { to } \\
-1.9 \%)\end{array}$ & 0.001 \\
\hline $\begin{array}{l}\text { Anaheim-Santa } \\
\text { Ana }\end{array}$ & $\begin{array}{l}\text { Gustavo } \\
\text { Najera }\end{array}$ & $\begin{array}{l}2016 \\
\text { Q1 }\end{array}$ & $\begin{array}{l}1.7 \%(-13.6 \% \text { to } \\
17.1 \%)\end{array}$ & 0.774 & $\begin{array}{l}-2.5 \%(-3.9 \% \text { to } \\
-1.0 \%)\end{array}$ & $<0.001$ & $\begin{array}{l}15.9 \%(-5.8 \% \text { to } \\
37.7 \%)\end{array}$ & 0.063 & $\begin{array}{l}0.063(-0.9 \% \text { to } \\
3.2 \%)\end{array}$ & 0.137 \\
\hline Atlanta & Anthony Hill & $\begin{array}{l}2016 \\
\text { Q1 }\end{array}$ & $\begin{array}{l}72.4 \%(-54.6 \% \text { to } \\
199.3 \%)\end{array}$ & 0.147 & $\begin{array}{l}-12.2 \%(-25.0 \% \\
\text { to } 0.7 \%)\end{array}$ & 0.018 & $\begin{array}{l}-41.1 \%(-220.6 \% \\
\text { to } 138.4 \%)\end{array}$ & 0.557 & $\begin{array}{l}0.557(-4.1 \% \text { to } \\
32.3 \%)\end{array}$ & 0.051 \\
\hline Aurora & $\begin{array}{l}\text { Naeschylus } \\
\text { Vinzant }\end{array}$ & $\begin{array}{l}2015 \\
\text { Q1 }\end{array}$ & $\begin{array}{l}95.6 \%(-1.6 \% \text { to } \\
192.9 \%)\end{array}$ & 0.014 & $\begin{array}{l}1.6 \% \text { ( }-7.9 \% \text { to } \\
11.1 \%)\end{array}$ & 0.665 & $\begin{array}{l}-101.5 \%(-239.0 \% \\
\text { to } 36.0 \%)\end{array}$ & 0.062 & $\begin{array}{l}0.062(-6.6 \% \text { to } \\
20.2 \%)\end{array}$ & 0.197 \\
\hline Austin & David Joseph & $\begin{array}{l}2016 \\
\text { Q1 }\end{array}$ & $\begin{array}{l}22.7 \% \text { ( } 8.8 \% \text { to } \\
36.6 \%)\end{array}$ & $<0.001$ & $\begin{array}{l}-0.8 \%(-2.3 \% \text { to } \\
0.7 \%)\end{array}$ & 0.159 & $\begin{array}{l}-24.5 \%(-44.1 \% \text { to } \\
-4.9 \%)\end{array}$ & 0.002 & $\begin{array}{l}0.002(-0.1 \% \text { to } \\
4.0 \%)\end{array}$ & 0.02 \\
\hline Bakersfield & $\begin{array}{l}\text { Francisco } \\
\text { Serna }\end{array}$ & $\begin{array}{l}2016 \\
Q 4\end{array}$ & $\begin{array}{l}103.9 \% \text { ( }-8.9 \% \text { to } \\
216.7 \%)\end{array}$ & 0.021 & $\begin{array}{l}-7.8 \%(-20.5 \% \text { to } \\
4.8 \%)\end{array}$ & 0.115 & $\begin{array}{l}-122.7 \%(-281.9 \% \\
\text { to } 36.6 \%)\end{array}$ & 0.052 & $\begin{array}{l}0.052(-7.6 \% \text { to } \\
28.0 \%)\end{array}$ & 0.146 \\
\hline Baton Rouge & Alton Sterling & $\begin{array}{l}2016 \\
\text { Q3 }\end{array}$ & $\begin{array}{l}446.3 \%(49.3 \% \\
\text { to } 843.2 \%)\end{array}$ & 0.005 & $\begin{array}{l}4.7 \%(-37.1 \% \text { to } \\
46.4 \%)\end{array}$ & 0.775 & $\begin{array}{l}-273.3 \%(-834.6 \% \\
\text { to } 288.1 \%)\end{array}$ & 0.215 & $\begin{array}{l}0.215(-55.1 \% \text { to } \\
63.0 \%)\end{array}$ & 0.864 \\
\hline $\begin{array}{l}\text { Charleston-North } \\
\text { Charleston }\end{array}$ & Walter Scott & $\begin{array}{l}2015 \\
\text { Q2 }\end{array}$ & $\begin{array}{l}80.1 \% \text { ( } 27.6 \% \text { to } \\
132.6 \%)\end{array}$ & $<0.001$ & $\begin{array}{l}-7.3 \%(-12.2 \% \text { to } \\
-2.5 \%)\end{array}$ & $<0.001$ & $\begin{array}{l}-110.6 \%(-184.8 \% \\
\text { to }-36.4 \%)\end{array}$ & $<0.001$ & $\begin{array}{l}<0.001 \text { ( } 7.5 \% \text { to } \\
21.1 \%)\end{array}$ & $<0.001$ \\
\hline Charlotte & $\begin{array}{l}\text { Keith Lamont } \\
\text { Scott }\end{array}$ & $\begin{array}{l}2016 \\
Q 3\end{array}$ & $\begin{array}{l}45.5 \% \text { ( } 4.2 \% \text { to } \\
86.8 \%)\end{array}$ & 0.006 & $\begin{array}{l}2.2 \%(-2.1 \% \text { to } \\
6.6 \%)\end{array}$ & 0.189 & $\begin{array}{l}-14.3 \% \text { ( }-72.4 \% \text { to } \\
43.7 \%)\end{array}$ & 0.527 & $\begin{array}{l}0.527 \text { ( }-11.3 \% \text { to } \\
0.8 \%)\end{array}$ & 0.029 \\
\hline Chicago & $\begin{array}{l}\text { Laquan } \\
\text { McDonald }\end{array}$ & $\begin{array}{l}2015 \\
Q 4\end{array}$ & $\begin{array}{l}332.4 \%(243.0 \% \\
\text { to } 421.8 \%)\end{array}$ & $<0.001$ & $\begin{array}{l}-19.3 \%(-27.7 \% \\
\text { to }-10.8 \%)\end{array}$ & $<0.001$ & $\begin{array}{l}-223.1 \%(-349.0 \% \\
\text { to }-97.3 \%)\end{array}$ & $<0.001$ & $\begin{array}{l}<0.001 \text { ( } 5.5 \% \text { to } \\
29.3 \%)\end{array}$ & $<0.001$ \\
\hline Cincinnati & $\begin{array}{l}\text { Samuel } \\
\text { DuBose }\end{array}$ & $\begin{array}{l}2015 \\
Q 3\end{array}$ & $\begin{array}{l}-18.5 \%(-228.3 \% \\
\text { to } 191.3 \%)\end{array}$ & 0.821 & $\begin{array}{l}-9.4 \%(-29.1 \% \text { to } \\
10.4 \%)\end{array}$ & 0.227 & $\begin{array}{l}46.6 \%(-249.8 \% \text { to } \\
343.0 \%)\end{array}$ & 0.687 & $\begin{array}{l}0.687(-10.8 \% \text { to } \\
45.0 \%)\end{array}$ & 0.120 \\
\hline Cleveland & Tamir Rice & $\begin{array}{l}2015 \\
Q 4\end{array}$ & $\begin{array}{l}401.6 \%(196.8 \% \\
\text { to } 606.3 \%)\end{array}$ & $<0.001$ & $\begin{array}{l}-19.8 \%(-38.7 \% \\
\text { to }-1.0 \%)\end{array}$ & 0.009 & $\begin{array}{l}-240.5 \%(-529.2 \% \\
\text { to } 48.3 \%)\end{array}$ & 0.036 & $\begin{array}{l}0.036 \text { ( } 7.2 \% \text { to } \\
60.4 \%)\end{array}$ & 0.002 \\
\hline Columbus & Henry Green & $\begin{array}{l}2016 \\
\text { Q3 }\end{array}$ & $\begin{array}{l}212.0 \%(120.0 \% \\
\text { to } 304.0 \%)\end{array}$ & $<0.001$ & $\begin{array}{l}-16.4 \%(-26.0 \% \\
\text { to }-6.7 \%)\end{array}$ & $<0.001$ & $\begin{array}{l}-250.3 \%(-380.2 \% \\
\text { to }-120.5 \%)\end{array}$ & $<0.001$ & $\begin{array}{l}<0.001 \text { ( } 5.2 \% \text { to } \\
32.5 \%)\end{array}$ & $<0.001$ \\
\hline
\end{tabular}




\begin{tabular}{|c|c|c|c|c|c|c|c|c|c|c|}
\hline $\begin{array}{l}\text { Dallas-Fort Worth- } \\
\text { Arlington }\end{array}$ & $\begin{array}{l}\text { Christian } \\
\text { Taylor }\end{array}$ & $\begin{array}{l}2015 \\
Q 3\end{array}$ & $\begin{array}{l}49.0 \%(-1.3 \% \text { to } \\
99.3 \%)\end{array}$ & 0.015 & $\begin{array}{l}1.9 \% \text { ( }-2.9 \% \text { to } \\
6.6 \%)\end{array}$ & 0.316 & $\begin{array}{l}-35.8 \%(-106.8 \% \\
\text { to } 35.3 \%)\end{array}$ & 0.199 & $\begin{array}{l}0.199(-4.4 \% \text { to } \\
9.0 \%)\end{array}$ & 0.378 \\
\hline Denver & $\begin{array}{l}\text { Ramone } \\
\text { Lonergan }\end{array}$ & $\begin{array}{l}2016 \\
\text { Q1 }\end{array}$ & $\begin{array}{l}41.6 \%(-197.4 \% \\
\text { to } 280.6 \%)\end{array}$ & 0.656 & $\begin{array}{l}6.7 \% \text { ( }-16.4 \% \text { to } \\
29.8 \%)\end{array}$ & 0.457 & $\begin{array}{l}239.9 \% \text { ( }-96.6 \% \text { to } \\
576.3 \%)\end{array}$ & 0.071 & $\begin{array}{l}0.071(-34.4 \% \text { to } \\
30.7 \%)\end{array}$ & 0.884 \\
\hline Detroit & $\begin{array}{l}\text { Terrance } \\
\text { Kellom }\end{array}$ & $\begin{array}{l}2015 \\
\text { Q2 }\end{array}$ & $\begin{array}{l}-8.6 \%(-249.6 \% \text { to } \\
232.4 \%)\end{array}$ & 0.927 & $\begin{array}{l}5.8 \% \text { ( - }-17.1 \% \text { to } \\
28.7 \%)\end{array}$ & 0.517 & $\begin{array}{l}26.8 \%(-313.7 \% \text { to } \\
367.4 \%)\end{array}$ & 0.840 & $\begin{array}{l}0.840(-27.5 \% \text { to } \\
37.3 \%)\end{array}$ & 0.696 \\
\hline Durham & $\begin{array}{l}\text { Frank } \\
\text { Nathaniel } \\
\text { Clark }\end{array}$ & $\begin{array}{l}2016 \\
\text { Q4 }\end{array}$ & $\begin{array}{l}-101.8 \%(-270.4 \% \\
\text { to } 66.7 \%)\end{array}$ & 0.125 & $\begin{array}{l}10.3 \% \text { ( }-8.5 \% \text { to } \\
29.1 \%)\end{array}$ & 0.164 & $\begin{array}{l}74.0 \% \text { (-164.4\% to } \\
312.3 \%)\end{array}$ & 0.427 & $\begin{array}{l}0.427(-38.6 \% \text { to } \\
14.6 \%)\end{array}$ & 0.250 \\
\hline Fresno & Dylan Noble & $\begin{array}{l}2016 \\
\text { Q2 }\end{array}$ & $\begin{array}{l}65.9 \% \text { ( } 36.5 \% \text { to } \\
95.2 \%)\end{array}$ & $<0.001$ & $\begin{array}{l}-7.8 \%(-11.6 \% \text { to } \\
-4.0 \%)\end{array}$ & $<0.001$ & $\begin{array}{l}32.1 \%(-9.4 \% \text { to } \\
73.6 \%)\end{array}$ & 0.051 & $\begin{array}{l}0.051(-1.9 \% \text { to } \\
8.8 \%)\end{array}$ & 0.103 \\
\hline Houston & Sandra Bland & $\begin{array}{l}2015 \\
\text { Q3 }\end{array}$ & $\begin{array}{l}43.2 \%(-17.5 \% \text { to } \\
103.9 \%)\end{array}$ & 0.072 & $\begin{array}{l}-8.0 \%(-13.7 \% \text { to } \\
-2.3 \%)\end{array}$ & $<0.001$ & $\begin{array}{l}-12.5 \%(-98.4 \% \text { to } \\
73.4 \%)\end{array}$ & 0.709 & $\begin{array}{l}0.709 \text { ( } 6.9 \% \text { to } \\
23.1 \%)\end{array}$ & $<0.001$ \\
\hline Indianapolis & Mack Long & $\begin{array}{l}2015 \\
\text { Q2 }\end{array}$ & $\begin{array}{l}59.8 \%(-31.0 \% \text { to } \\
150.6 \%)\end{array}$ & 0.095 & $\begin{array}{l}-13.9 \%(-20.8 \% \\
\text { to }-7.0 \%)\end{array}$ & $<0.001$ & $\begin{array}{l}55.5 \%(-72.8 \% \text { to } \\
183.8 \%)\end{array}$ & 0.270 & $\begin{array}{l}0.270(-6.2 \% \text { to } \\
13.3 \%)\end{array}$ & 0.347 \\
\hline Long Beach & Feras Morad & $\begin{array}{l}2015 \\
\text { Q2 }\end{array}$ & $\begin{array}{l}49.7 \% \text { ( }-50.0 \% \text { to } \\
149.5 \%)\end{array}$ & 0.204 & $\begin{array}{l}1.4 \% \text { ( }-8.1 \% \text { to } \\
10.9 \%)\end{array}$ & 0.704 & $\begin{array}{l}2.3 \%(-138.7 \% \text { to } \\
143.3 \%)\end{array}$ & 0.967 & $\begin{array}{l}0.967(-14.5 \% \text { to } \\
12.3 \%)\end{array}$ & 0.835 \\
\hline Los Angeles & Ezell Ford & $\begin{array}{l}2014 \\
\text { Q3 }\end{array}$ & $\begin{array}{l}39.0 \% \text { ( } 6.4 \% \text { to } \\
71.7 \% \text { ) }\end{array}$ & 0.003 & $\begin{array}{l}1.7 \% \text { ( }-1.8 \% \text { to } \\
5.3 \%)\end{array}$ & 0.206 & $\begin{array}{l}26.1 \%(-20.1 \% \text { to } \\
72.3 \%)\end{array}$ & 0.150 & $\begin{array}{l}0.150(-1.9 \% \text { to } \\
8.0 \%)\end{array}$ & 0.122 \\
\hline Louisville & $\begin{array}{l}\text { Deng } \\
\text { Manyoun }\end{array}$ & $\begin{array}{l}2015 \\
\text { Q1 }\end{array}$ & $\begin{array}{l}151.6 \% \text { ( } 10.8 \% \\
\text { to } 292.3 \%)\end{array}$ & 0.008 & $\begin{array}{l}-10.2 \%(-27.3 \% \\
\text { to } 7.0 \%)\end{array}$ & 0.135 & $\begin{array}{l}-102.2 \%(-301.2 \% \\
\text { to } 96.8 \%)\end{array}$ & 0.193 & $\begin{array}{l}0.193(-13.8 \% \text { to } \\
34.8 \%)\end{array}$ & 0.270 \\
\hline Memphis & $\begin{array}{l}\text { Darrius } \\
\text { Stewart }\end{array}$ & $\begin{array}{l}2015 \\
Q 4\end{array}$ & $\begin{array}{l}168.1 \% \text { ( } 91.8 \% \\
\text { to } 244.3 \%)\end{array}$ & $<0.001$ & $\begin{array}{l}-3.8 \%(-10.3 \% \text { to } \\
2.8 \%)\end{array}$ & 0.141 & $\begin{array}{l}-135.5 \%(-243.0 \% \\
\text { to }-28.0 \%)\end{array}$ & 0.002 & $\begin{array}{l}0.002(-2.1 \% \text { to } \\
16.3 \%)\end{array}$ & 0.051 \\
\hline Milwaukee & Sylville Smith & $\begin{array}{l}2016 \\
Q 3\end{array}$ & $\begin{array}{l}\text { 65.9\% ( }-29.6 \% \text { to } \\
161.3 \%)\end{array}$ & 0.081 & $\begin{array}{l}-33.3 \%(-42.5 \% \\
\text { to }-24.1 \%)\end{array}$ & $<0.001$ & $\begin{array}{l}-21.8 \%(-156.5 \% \\
\text { to } 113.0 \%)\end{array}$ & 0.679 & $\begin{array}{l}0.679 \text { ( } 8.5 \% \text { to } \\
34.4 \%)\end{array}$ & $<0.001$ \\
\hline $\begin{array}{l}\text { Minneapolis-St } \\
\text { Paul }\end{array}$ & Jamar Clark & $\begin{array}{l}2015 \\
Q 4\end{array}$ & $\begin{array}{l}4.8 \% \text { ( }-84.7 \% \text { to } \\
94.2 \%)\end{array}$ & 0.891 & $\begin{array}{l}5.1 \% \text { ( }-7.0 \% \text { to } \\
17.3 \%)\end{array}$ & 0.283 & $\begin{array}{l}19.7 \%(-105.9 \% \text { to } \\
145.3 \%)\end{array}$ & 0.688 & $\begin{array}{l}0.688(-25.1 \% \text { to } \\
9.2 \%)\end{array}$ & 0.239 \\
\hline New Orleans & Eric Harris & $\begin{array}{l}2016 \\
\text { Q1 }\end{array}$ & $\begin{array}{l}451.8 \%(288.7 \% \\
\text { to } 614.8 \%)\end{array}$ & $<0.001$ & $\begin{array}{l}-9.5 \%(-23.4 \% \text { to } \\
4.3 \%)\end{array}$ & 0.081 & $\begin{array}{l}-317.0 \%(-547.6 \% \\
\text { to }-86.4 \%)\end{array}$ & $<0.001$ & $\begin{array}{l}<0.001 \text { ( } 6.0 \% \text { to } \\
45.2 \%)\end{array}$ & 0.001 \\
\hline New York & Eric Garner & $\begin{array}{l}2014 \\
Q 4\end{array}$ & $\begin{array}{l}17.8 \%(-1.4 \% \text { to } \\
37.0 \%)\end{array}$ & 0.020 & $\begin{array}{l}4.4 \%(2.5 \% \text { to } \\
6.4 \%)\end{array}$ & $<0.001$ & $\begin{array}{l}-24.6 \%(-51.6 \% \text { to } \\
2.5 \%)\end{array}$ & 0.023 & $\begin{array}{l}0.023(-7.4 \% \text { to } \\
-1.9 \%)\end{array}$ & $<0.001$ \\
\hline Philadelphia & $\begin{array}{l}\text { Christopher } \\
\text { Sowell }\end{array}$ & $\begin{array}{l}2016 \\
Q 3\end{array}$ & $\begin{array}{l}157.3 \%(-18.0 \% \\
\text { to } 332.5 \%)\end{array}$ & 0.024 & $\begin{array}{l}-0.5 \%(-18.8 \% \text { to } \\
17.7 \%)\end{array}$ & 0.939 & $\begin{array}{l}-84.1 \%(-331.9 \% \\
\text { to } 163.6 \%)\end{array}$ & 0.385 & $\begin{array}{l}0.385(-33.1 \% \text { to } \\
18.5 \%)\end{array}$ & 0.469 \\
\hline
\end{tabular}




\begin{tabular}{|c|c|c|c|c|c|c|c|c|c|c|c|c|}
\hline Greater Phoenix & Daniel Shaver & $\begin{array}{l}2016 \\
\text { Q1 }\end{array}$ & $\begin{array}{l}51.4 \% \text { ( } 23.8 \% \text { to } \\
79.1 \%)\end{array}$ & $<0.001$ & $\begin{array}{l}-1.6 \% \text { ( }-4.1 \% \text { to } \\
0.9 \%)\end{array}$ & 0.097 & & $\begin{array}{l}-20.6 \% \text { ( }-59.8 \% \text { to } \\
18.5 \%)\end{array}$ & 0.179 & $\begin{array}{l}0.179(-0.9 \% \text { to } \\
6.1 \%)\end{array}$ & 0.059 & \\
\hline Raleigh & Akiel Denkins & $\begin{array}{l}2016 \\
\text { Q1 }\end{array}$ & $\begin{array}{l}108.3 \%(77.9 \% \\
\text { to } 138.8 \%)\end{array}$ & $<0.001$ & $\begin{array}{l}-7.2 \% \text { ( }-11.4 \% \text { to } \\
-2.9 \%)\end{array}$ & $<0.001$ & & $\begin{array}{l}-112.6 \%(-155.7 \% \\
\text { to }-69.6 \%)\end{array}$ & $<0.001$ & $\begin{array}{l}<0.001 \text { ( } 4.8 \% \text { to } \\
16.8 \%)\end{array}$ & $<0.001$ & \\
\hline Sacramento & $\begin{array}{l}\text { Dazion } \\
\text { Flenaugh }\end{array}$ & $\begin{array}{l}2016 \\
\text { Q2 }\end{array}$ & $\begin{array}{l}5.7 \%(-24.4 \% \text { to } \\
35.9 \%)\end{array}$ & 0.626 & $\begin{array}{l}-4.1 \% \text { ( }-7.2 \% \text { to } \\
-1.1 \%)\end{array}$ & $<0.001$ & & $\begin{array}{l}-8.0 \% \text { ( }-50.6 \% \text { to } \\
34.6 \%)\end{array}$ & 0.631 & $\begin{array}{l}0.631(-1.9 \% \text { to } \\
6.7 \%)\end{array}$ & 0.158 & \\
\hline San Antonio & $\begin{array}{l}\text { Antronie } \\
\text { Scott }\end{array}$ & $\begin{array}{l}2016 \\
\text { Q1 }\end{array}$ & $\begin{array}{l}102.6 \%(45.7 \% \\
\text { to } 159.4 \%)\end{array}$ & $<0.001$ & $\begin{array}{l}-7.9 \%(-13.4 \% \text { to } \\
-2.4 \%)\end{array}$ & $<0.001$ & & $\begin{array}{l}-60.6 \%(-141.1 \% \\
\text { to } 19.8 \%)\end{array}$ & 0.057 & $\begin{array}{l}0.057(-1.5 \% \text { to } \\
14.0 \%)\end{array}$ & 0.043 & \\
\hline San Diego & $\begin{array}{l}\text { Lamontez } \\
\text { Jones }\end{array}$ & $\begin{array}{l}2015 \\
Q 4\end{array}$ & $\begin{array}{l}40.7 \% \text { ( } 5.6 \% \text { to } \\
75.9 \%)\end{array}$ & 0.004 & $\begin{array}{l}0.4 \%(-2.9 \% \text { to } \\
3.7 \%)\end{array}$ & 0.755 & & $\begin{array}{l}-44.6 \%(-94.3 \% \text { to } \\
5.1 \%)\end{array}$ & 0.024 & $\begin{array}{l}0.024(-5.0 \% \text { to } \\
4.4 \%)\end{array}$ & 0.857 & \\
\hline San Francisco & Mario Woods & $\begin{array}{l}2015 \\
\text { Q4 }\end{array}$ & $\begin{array}{l}67.7 \% \text { ( } 31.5 \% \text { to } \\
103.9 \%)\end{array}$ & $<0.001$ & $\begin{array}{l}-2.7 \%(-5.6 \% \text { to } \\
0.2 \%)\end{array}$ & 0.021 & & $\begin{array}{l}-92.3 \%(-143.5 \% \\
\text { to }-41.0 \%)\end{array}$ & $<0.001$ & $\begin{array}{l}<0.001(-4.2 \% \\
\text { to } 4.0 \%)\end{array}$ & 0.949 & \\
\hline St Louis & $\begin{array}{l}\text { Michael } \\
\text { Brown }\end{array}$ & $\begin{array}{l}2014 \\
Q 4\end{array}$ & $\begin{array}{l}449.8 \% \text { ( } 308.6 \% \\
\text { to } 590.9 \%)\end{array}$ & $<0.001$ & $\begin{array}{l}-7.0 \%(-20.7 \% \text { to } \\
6.8 \%)\end{array}$ & 0.196 & & $\begin{array}{l}-263.0 \%(-462.1 \% \\
\text { to }-64.0 \%)\end{array}$ & 0.001 & $\begin{array}{l}0.001 \text { ( } 14.4 \% \text { to } \\
53.3 \%)\end{array}$ & $<0.001$ & \\
\hline Seattle & Che Taylor & $\begin{array}{l}2016 \\
\text { Q1 }\end{array}$ & $\begin{array}{l}-25.7 \%(-68.6 \% \text { to } \\
17.2 \%)\end{array}$ & 0.128 & $\begin{array}{l}3.4 \%(0.0 \% \text { to } \\
6.9 \%)\end{array}$ & 0.014 & & $\begin{array}{l}\text { 45.9\% ( }-14.7 \% \text { to } \\
106.5 \%)\end{array}$ & 0.056 & $\begin{array}{l}0.056(-7.9 \% \text { to } \\
1.7 \%)\end{array}$ & 0.103 & \\
\hline Stockton & Matautu Nuu & $\begin{array}{l}2015 \\
\text { Q1 }\end{array}$ & $\begin{array}{l}194.4 \%(102.3 \% \\
\text { to } 286.4 \%)\end{array}$ & $<0.001$ & $\begin{array}{l}8.4 \% \text { ( } 1.1 \% \text { to } \\
15.7 \%)\end{array}$ & 0.005 & & $\begin{array}{l}-130.3 \%(-260.4 \% \\
\text { to }-0.2 \%)\end{array}$ & 0.012 & $\begin{array}{l}0.012(-12.1 \% \text { to } \\
8.6 \%)\end{array}$ & 0.666 & \\
\hline Tampa & $\begin{array}{l}\text { Levonia } \\
\text { Riggins }\end{array}$ & $\begin{array}{l}2016 \\
Q 3\end{array}$ & $\begin{array}{l}78.2 \% \text { ( } 3.6 \% \text { to } \\
152.8 \%)\end{array}$ & 0.009 & $\begin{array}{l}-12.1 \%(-23.3 \% \\
\text { to }-0.8 \%)\end{array}$ & 0.008 & & $\begin{array}{l}-67.7 \%(-173.1 \% \\
\text { to } 37.8 \%)\end{array}$ & 0.104 & $\begin{array}{l}0.104 \text { ( }-7.4 \% \text { to } \\
24.4 \%)\end{array}$ & 0.176 & \\
\hline Tulsa & Eric Harris & $\begin{array}{l}2015 \\
\text { Q2 }\end{array}$ & $\begin{array}{l}64.8 \%(-59.3 \% \text { to } \\
188.9 \%)\end{array}$ & 0.184 & $\begin{array}{l}-2.2 \% \text { ( }-14.0 \% \text { to } \\
9.6 \%)\end{array}$ & 0.627 & & $\begin{array}{l}20.8 \%(-154.7 \% \text { to } \\
196.3 \%)\end{array}$ & 0.761 & $\begin{array}{l}0.761(-7.2 \% \text { to } \\
26.2 \%)\end{array}$ & 0.148 & \\
\hline Washington DC & $\begin{array}{l}\text { Terrence } \\
\text { Sterling }\end{array}$ & $\begin{array}{l}2016 \\
Q 3\end{array}$ & $\begin{array}{l}-142.6 \%(-290.1 \% \\
\text { to } 5.0 \%)\end{array}$ & 0.016 & $\begin{array}{l}8.7 \%(-6.8 \% \text { to } \\
24.2 \%)\end{array}$ & & 0.155 & $\begin{array}{l}30.3 \%(-178.1 \% \text { to } \\
238.7 \%)\end{array}$ & 0.710 & $\begin{array}{l}0.710(-32.3 \% \text { to } \\
11.5 \%)\end{array}$ & & 0.226 \\
\hline Wichita & $\begin{array}{l}\text { John Paul } \\
\text { Quintero }\end{array}$ & $\begin{array}{l}2015 \\
\text { Q1 }\end{array}$ & $\begin{array}{l}62.6 \% \text { ( }-40.6 \% \text { to } \\
165.7 \%)\end{array}$ & 0.123 & $\begin{array}{l}6.7 \% \text { ( }-3.4 \% \text { to } \\
16.8 \%)\end{array}$ & & 0.091 & $\begin{array}{l}-36.0 \%(-181.8 \% \\
\text { to } 109.9 \%)\end{array}$ & 0.527 & $\begin{array}{l}0.527(-18.0 \% \text { to } \\
10.5 \%)\end{array}$ & & 0.503 \\
\hline Summary & NA & NA & $\begin{array}{l}26.1 \% \text { ( } 15.3 \% \text { to } \\
36.8 \%)\end{array}$ & $<0.001$ & $\begin{array}{l}-0.7 \%(-2.0 \% \text { to } \\
0.5 \%)\end{array}$ & & 0.132 & $\begin{array}{l}-15.2 \% \text { ( }-26.7 \% \text { to } \\
-3.6 \%)\end{array}$ & 0.001 & $\begin{array}{l}0.001 \text { ( } 0.1 \% \text { to } \\
2.4 \%)\end{array}$ & & 0.006 \\
\hline
\end{tabular}


Supplementary table 3. Results of interrupted time series on proportion of aggravated assaults reported to police based on responses to the National Crime Victimization Survey (Bureau of Justice Statistics, 2019)

\begin{tabular}{|c|l|r|}
\hline & Effect $(99 \% \mathrm{Cl})$ & $p$-value \\
\hline All respondents & & \\
\hline Acute & $6.1 \%(-31.4 \%$ to $43.5 \%)$ & 0.652 \\
\hline Gradual & $-4.1 \%(-12.6 \%$ to $4.3 \%)$ & 0.183 \\
\hline Black respondents & & \\
\hline Acute & $17.9 \%(-79.2 \%$ to $115 \%)$ & 0.608 \\
\hline Gradual & $-6.1 \%(-28.1 \%$ to $15.9 \%)$ & 0.441 \\
\hline
\end{tabular}

